\title{
Impact of stratospheric variability on tropospheric climate change
}

\author{
Mauro Dall'Amico · Peter A. Stott • \\ Adam A. Scaife · Lesley J. Gray • \\ Karen H. Rosenlof · Alexey Yu. Karpechko
}

Received: 5 September 2008/Accepted: 13 April 2009/Published online: 18 July 2009

(C) Crown Copyright 2009

\begin{abstract}
An improved stratospheric representation has been included in simulations with the Hadley Centre HadGEM1 coupled ocean atmosphere model with natural and anthropogenic forcings for the period 1979-2003. An improved stratospheric ozone dataset is employed that includes natural variations in ozone as well as the usual anthropogenic trends. In addition, in a second set of simulations the quasi biennial oscillation (QBO) of stratospheric equatorial zonal wind is also imposed using a relaxation towards ERA-40 zonal wind values. The resulting impact on tropospheric variability and trends is described. We show that the modelled cooling rate at the tropopause is enhanced by the improved ozone dataset and this improvement is even more marked when the QBO is also included. The same applies to warming trends in the upper tropical troposphere which are slightly reduced. Our stratospheric improvements produce a significant increase of internal variability but no change in the positive trend of
\end{abstract}

M. Dall'Amico · L. J. Gray

NCAS Climate, University of Reading, Reading, UK

Present Address:

M. Dall'Amico ( $\square)$

Deutsches Zentrum für Luft- und Raumfahrt, Institut für Physik der Atmosphäre, Oberpfaffenhofen, Germany

e-mail: Mauro.DallAmico@dlr.de

P. A. Stott - A. A. Scaife

Met Office Hadley Centre, Exeter, UK

K. H. Rosenlof

NOAA Earth System Research Laboratory, Boulder, CO, USA

A. Yu. Karpechko

Climatic Research Unit, School of Environmental Sciences,

University of East Anglia, Norwich, UK annual mean global mean near-surface temperature. Warming rates are increased significantly over a large portion of the Arctic Ocean. The improved stratospheric representation, especially the QBO relaxation, causes a substantial reduction in near-surface temperature and precipitation response to the El Chichón eruption, especially in the tropical region. The winter increase in the phase of the northern annular mode observed in the aftermath of the two major recent volcanic eruptions is partly captured, especially after the El Chichón eruption. The positive trend in the southern annular mode (SAM) is increased and becomes statistically significant which demonstrates that the observed increase in the SAM is largely subject to internal variability in the stratosphere. The possible inclusion in simulations for future assessments of full ozone chemistry and a gravity wave scheme to internally generate a QBO is discussed.

Keywords Simulations of recent climate with natural and anthropogenic forcings assessed by the IPCC 2007

AR4 - Observed ozone distributions · Quasi-biennial oscillation (QBO) of stratospheric equatorial zonal wind . Variability and trends at the tropopause and in the troposphere - Response to the volcanic eruptions of El Chichón and Mt. Pinatubo

\section{Introduction}

The stratosphere plays an important role in the climate system and shows a large natural climate variability related to sudden stratospheric warmings, the quasi-biennial oscillation (QBO) of stratospheric equatorial zonal wind (Reed et al. 1961; Veryard and Ebdon 1961; see the review by Baldwin et al. 2001), the 11-year solar cycle 
(e.g. Labitzke and van Loon 1999), the impact of volcanic eruptions (e.g. Labitzke and van Loon 1999), the phase of the El Niño Southern Oscillation (ENSO) and the annular modes (Van Loon and Labitzke 1987; Thompson and Wallace 2000). The stratosphere also bears the signature of anthropogenic forcings through the processes related to ozone depletion and increased greenhouse gas concentration. In recent years, there has been increasing evidence that the stratosphere can influence tropospheric climate (e.g. Houghton et al. 2001, pp. 432-435; Kindem and Christiansen 2001; Scaife et al. 2005) from the tropopause down to the surface (e.g. Baldwin and Dunkerton 1999; Black 2002; Thompson and Solomon 2002; Gillet and Thompson 2003; Santer et al. 2003, Seidel and Randel 2006; Dall'Amico and Egger 2007).

Despite the growing evidence for the importance of the stratosphere, some of the simulations of recent climate assessed by the Intergovernmental Panel on Climate Change 2007 Fourth assessment Report (henceforth AR4) did not include a stratospheric ozone trend (Cordero and Forster 2006). In those that did, the trend was imposed in a relatively simple way. For example, in the simulations conducted by the UK Met Office Hadley Centre (Stott et al. 2006), a monthly mean ozone climatology with superimposed trends was specified. Cordero and Forster (2006) found that there are significant differences between observations and model trends, particularly in the upper tropical troposphere (100-200 hPa) where, since 1979, models show a warming trend and the observations show a cooling trend. Forster et al. (2007) have suggested that this discrepancy may be due to an inadequate representation of stratospheric ozone at pressures below about $70 \mathrm{hPa}$, the effect of which can penetrate into the upper troposphere to at least $150 \mathrm{hPa}$. The standard treatment of ozone changes also means that ozone variations associated with the solar cycle (e.g. Randel and Wu 2007), the QBO (e.g. Gray and Pyle 1989; Baldwin et al. 2001) and volcanic eruptions (Randel and Wu 1995) were not included although irradiance changes associated with the 11-year solar cycle and volcanic eruptions are represented in many of the climate models (e.g. Stott et al. 2001). Such inter-annual ozone variations cause corresponding variations in heating rates, temperature and vertical ascent rates in the lower stratosphere which may then influence the troposphere (Haigh 2003; Croocks and Gray 2005; Haigh et al. 2005).

In addition, the models assessed by the AR4 do not generally include the QBO in zonal wind (see Randall et al. 2007, their Section 8.4.9), which may have severe impacts on the simulation of tropospheric climate. For example, the signal of the QBO may be found in the troposphere through induced changes of convection in the tropics (e.g. Collimore et al. 1998; 2003; Giorgetta et al. 1999) and also of the annular modes in the extra-tropics (e.g. Coughlin and
Tung 2001; Thompson et al. 2002). High latitude changes of the stratospheric polar vortex are thought to impact mid and high latitude tropospheric weather and climate, for example through changes in the northern annular mode (NAM, defined as the first EOF of NH geopotential height North of $20^{\circ} \mathrm{N}$ ) (Thompson and Wallace 2000) and position of the jet-stream (Boville 1984; Coughlin and Tung 2001; Norton 2003; Baldwin et al. 2003; Scaife et al. 2005; Dall'Amico and Egger 2007). The QBO also influences the high latitude volcanic response near the surface (Stenchikov et al. 2004).

The goal of this paper is to investigate the impact of observed ozone variability and the QBO on the troposphere in climate simulations of late twentieth century of the type conducted for the AR4. A discussion of the resulting changes in variability and trends in the stratosphere are described in a separate paper (Dall'Amico et al. 2009). In Sect. 2, we keep the descriptions of model and methodology to a minimum (more details can be found in Dall'Amico et al. 2009) and describe our main findings concerning the impact of stratospheric improvements on the model's troposphere in Sect. 3. Our conclusions are summarised in Sect. 4.

\section{Model simulations}

\subsection{The model}

The study employs the Hadley Centre global environmental model 1 (HadGEM1) described by Martin et al. (2006), Ringer et al. (2006) and Johns et al. (2006). The horizontal resolution of the atmospheric component is $1.25^{\circ}$ latitude by $1.875^{\circ}$ longitude and the model has 38 vertical levels from the surface to about $5 \mathrm{hPa}$. The model uses a hybrid height coordinate. The oceanic component of the model has a horizontal resolution of $1^{\circ}$ longitude-the meridional resolution is $1^{\circ}$ between the poles and $30^{\circ}$ latitude, from which it increases smoothly to $1 / 3^{\circ}$ at the equator (Johns et al. 2006).

The initial states for our three-member ensembles ${ }^{1}$ were created by running historical simulations with both anthropogenic and natural forcings from climate states sampled from a control simulation with pre-industrial atmospheric composition (Dall'Amico et al. 2009; Stott et al. 2006). Both the atmospheric (including soil) and the oceanic (including sea ice) initial states may be considered

\footnotetext{
1 Time and resources allowed to run three simulations at the time and three is generally recognised to be a reasonable minimum number of ensemble members. In terms of maximising the signal to noise ratio, the more members the better but the standard deviation reduces with $1 / \sqrt{n}$ which suggests diminishing returns as ensemble size is increased.
} 
to stem from unrelated distinct states of the climate system in its pre-industrial state. All model integrations were started at 00:00 UTC on 1 December 1978 and cover the 25-year period until 1 December 2003.

\section{2 'Baseline' simulations}

Our set of three reference or 'baseline' simulations are almost identical to the simulations described in Stott et al. (2006), the only differences arise from a different computing infrastructure and some recent minor bug fixes. The simulations include changes in well mixed greenhouse gases, tropospheric and stratospheric ozone, aerosols, land use, solar irradiance and stratospheric volcanic aerosols. Thus, natural forcings (mainly due to solar activity and volcanic eruptions) as well as anthropogenic ones (like changes in greenhouse gas concentrations and aerosol emissions) were included-see Tett et al. (2002, their Fig. 1) for a comparison of the forcings. The implementation of these forcings in the model is described in detail in Stott et al. (2006). All these forcings except stratospheric ozone are the same in all sets of simulations.

Ozone concentrations required in the radiative calculations are externally imposed as monthly mean profiles. In the baseline simulations up to 1990 , ozone concentrations are taken from the Stratospheric Processes and their Role in Climate (SPARC) dataset (Randel and Wu 1999; Randel et al. 1999; Kiehl et al. 1999). After 1990, estimates of stratospheric ozone were made assuming a linear relationship between effective equivalent stratospheric chlorine (EESC) and ozone changes (Daniel et al. 1995). Overall, stratospheric ozone consists of a climatology with superimposed trends but no inter-annual variations.
Tropospheric ozone fields were computed using an offline chemistry transport model. Further details are described in Stott et al. (2006).

\section{3 'Baseline+ozone' simulations}

A set of three improved 'baseline+ozone' simulations were run. The imposed ozone fields have been improved to provide a time series of stratospheric ozone that includes inter-annual variability associated with, e.g. the 11-year solar cycle, volcanic eruptions and the QBO. The stratospheric part of a new time series of observed ozone distributions for the period 1979-2003 was employed. These data were constructed using satellite observations from a variety of different instruments. Further details about the ozone employed here are described in Dall'Amico et al. (2009) in their Sect. 2.3 and in their appendixes. We note here that because the dataset has been compiled using multiple instruments and techniques, there is explicit information about inter-annual variations in ozone concentrations including the behaviour of ozone in the years immediately after each of the two major recent volcanic eruptions of El Chichón (February-March 1981) and Mt. Pinatubo (June 1992).

The improved ozone dataset and the baseline ozone have different background stratospheric ozone climatologies as discussed in Dall'Amico et al. (2009, see their Fig. 2). These differences are associated with changes in the temperature profile climatology in the stratosphere (Dall'Amico et al. 2009, their Fig. 3) that penetrate down to the tropopause (Fig. 2) and into the tropical upper troposphere causing a warming of about $0.4 \mathrm{~K}$ in the $7-15 \mathrm{~km}$ height region in the improved dataset compared to the baseline ozone (Fig. 3). Associated large-scale
Fig. 1 Time series of ensemble-mean global mean tropopause temperature $(\mathrm{K})$ from the baseline simulation (blue), the 'baseline+ozone' simulation (grey) and the 'baseline+ozone+QBO' simulation (red). The thin black line in this and in other figures describing time series gives a non-dimensional measure of global mean volcanic aerosol loading, showing the El

Chichón $(E)$ and Mt. Pinatubo $(P)$ eruptions

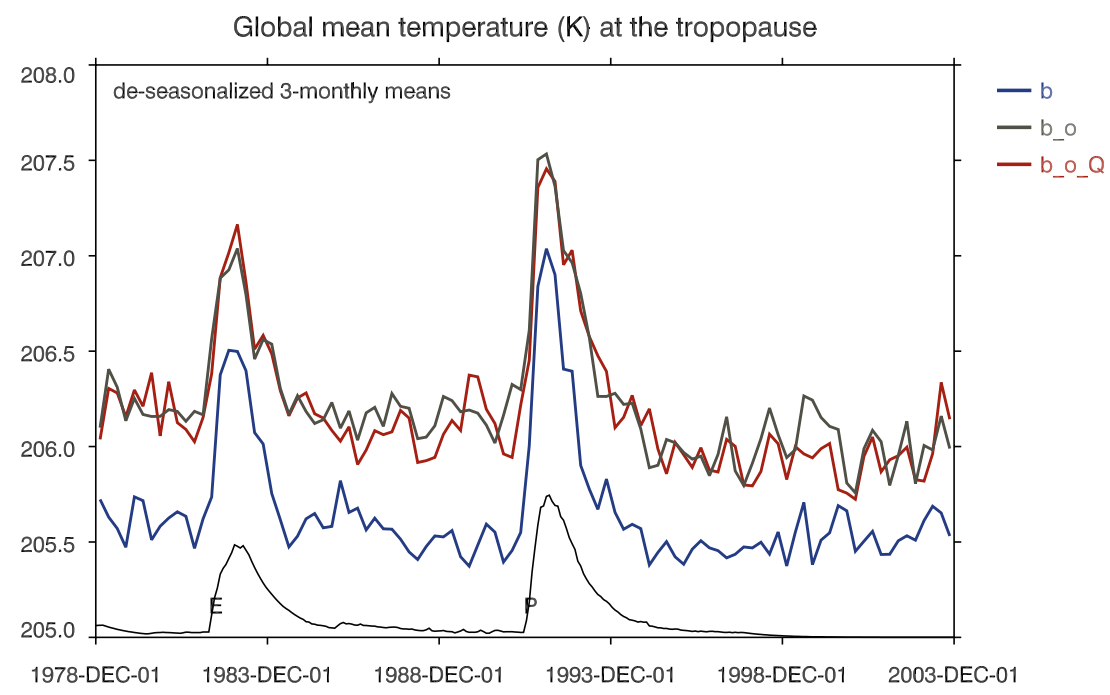


changes in zonal wind profile are confined to the stratosphere. These changes in the background ozone climatology did not appear to have significantly affected the variability of stratospheric temperatures. As for possible near-surface temperature impacts, the radiative forcing associated with the different background ozone climatology should be rather small. Stuber et al. (2005) applied an ozone perturbation of $315 \mathrm{DU}$ in the lower stratosphere of an experiment with a mixed-layer ocean and obtained a radiative forcing of $1 \mathrm{Wm}^{-2}$ and a surface response of only $1.46 \mathrm{~K}$. The small extent of the response can be explained through the competing effects of the ozone perturbations in the longwave and the shortwave radiation bands. The studies by Hansen et al. (1997) and Lacis et al. (1990) suggest that positive ozone perturbations in the lower stratosphere produce a small radiative forcing and that there is a level between 25 and $30 \mathrm{~km}$ where the radiative forcing is zero before it turns into a negative one at upper levels. Consistent with this, in our study with a coupled ocean, there is an immediate local temperature response at stratospheric levels in the perturbed sets of simulations, while the near-surface response is negligible in the baseline+ozone+QBO runs where the global warming trend is slightly but not significantly smaller than in the baseline (see Sect. 3.3.1 and the middle panel of Fig. 4).

\section{4 'Baseline+ozone+QBO' simulations}

In addition to the improved ozone distributions, in the 'baseline+ozone+QBO' simulations a scheme has been introduced to relax the stratospheric zonal winds at low latitudes towards appropriate QBO values obtained from ERA-40 re-analysis data (Uppala et al. 2005). The scheme is similar to that employed by Pascoe et al. (2005). At the end of each time-step the increment to the zonal wind is modified in the following way:

$u(t+\Delta t)-u(t)=\cdots-\Delta t * \alpha\left(u(t)-\beta * \bar{u}_{\mathrm{ERA}-40}(h, t)\right)$

where $\Delta t$ is the time step and $u$ is the zonal wind at any grid point. The relaxation rate $\alpha$ depends on height and latitude: it decreases rapidly moving away from the equator to 0.01 of the equatorial value at the edge of the tropics. At the equator, $\alpha$ grows smoothly with height from $1 / 4.3$ days $^{-1}$ at $18.5 \mathrm{~km}$ toward $1 / 0.5$ days $^{-1}$ at $40 \mathrm{~km}$. The latitudinal profile $\beta$ decays slowly from unity moving away from the equator to reach about 0.2 at the tropics. Altogether, we have employed a purely pragmatic approach and employed a profile that gives a zonal wind time series that resembles the observations. Further details of this scheme are described in Dall'Amico et al. (2009, their Section 2.4).

\section{Results}

\subsection{The tropopause}

Over the period 1979-2001, the global tropopause height increase associated with stratospheric cooling and tropospheric warming (e.g. Sausen and Santer 2003) was roughly $200 \mathrm{~m}$ in ERA-40 (Santer et al. 2004), giving a trend of about $90 \mathrm{~m}$ decade ${ }^{-1}$. Using 1980-2004 radiosonde data, Seidel and Randel (2006) estimated a somewhat lower rate of tropopause height increase of $64 \mathrm{~m}$ decade $^{-1}$. In the baseline and in the baseline + ozone + QBO simulations, the global tropopause height grows at a rate of $104 \pm 30 \mathrm{~m} \mathrm{decade}$ and $^{-1}$ and $\pm 70 \mathrm{~m} \mathrm{decade}$, $^{-1}$, respectively. A $t$ test (von Storch and Zwiers 1999, their Sect. 6.6.5) is conducted in the following way. The variance of an ensemble-mean value is one-third of the variance calculated across the values from the three ensemble members. The number of degrees of freedoms is estimated from the data as in von Storch and Zwiers (1999, their Sect. 6.6.5). The null hypothesis that trends from these two sets of simulations are consistent can not be rejected at the $10 \%$ level: the $P$ value, representing the chance of obtaining such a difference in trends if the null hypothesis is true, is 0.143 . The same applies to comparisons between either set of modelled trends with the above trends estimated from re-analysis and radiosonde data whereby observations are treated as a single realisation of the climate system.

While tropopause height has been increasing, the tropopause temperature has been decreasing. The improved stratospheric representation increases the magnitude of tropopause cooling trends, mainly due to the imposed observed ozone. Figure 1 shows the evolution of the ensemble-mean global mean tropopause temperature from our simulations. In the baseline and baseline+ozone $+\mathrm{QBO}$ simulations, the global tropopause temperature trends are $-0.10 \pm 0.02$ and $-0.18 \pm 0.03 \mathrm{~K}$ decade $^{-1}$, respectively. The low $P$ value of 0.091 suggests that the baseline+ozone+QBO simulation has made a substantial difference: we can reject the null hypothesis at the $10 \%$ level. The baseline+ozone trend lies in between with $-0.16 \pm 0.03 \mathrm{~K} \mathrm{decade}^{-1}$ Seidel and Randel (2006) estimated the tropopause temperature trend over this time period to be $-0.41 \mathrm{~K} \mathrm{decade}^{-1}$. The decline in the baseline+ozone + QBO simulations is almost double that of the baseline but is still only approximately half that observed by Seidel and Randel (2006), although large uncertainties remain due to internal variability and observational data problems. Futhermore, the strong cooling estimated by Seidel and Randel (2006) exacerbates the uncertainty surrounding the apparent increases in water vapour observations since a rapidly cooling tropopause would tend to reduce stratospheric water vapour. Tropopause temperature 
Fig. 2 Top as in Fig. 1 but for tropopause temperature $(\mathrm{K})$ in the equatorial region. Middle as in the top panel but for water vapour (ppmv) at $100 \mathrm{hPa}$ in the equatorial region. For all sets of simulations, the evolution of water vapour closely follows that of temperature. Bottom difference between the baseline+ozone+QBO and the baseline water vapour in the middle panel (ppmv)
Temperature $(\mathrm{K})$ at the tropopause in the equatorial region

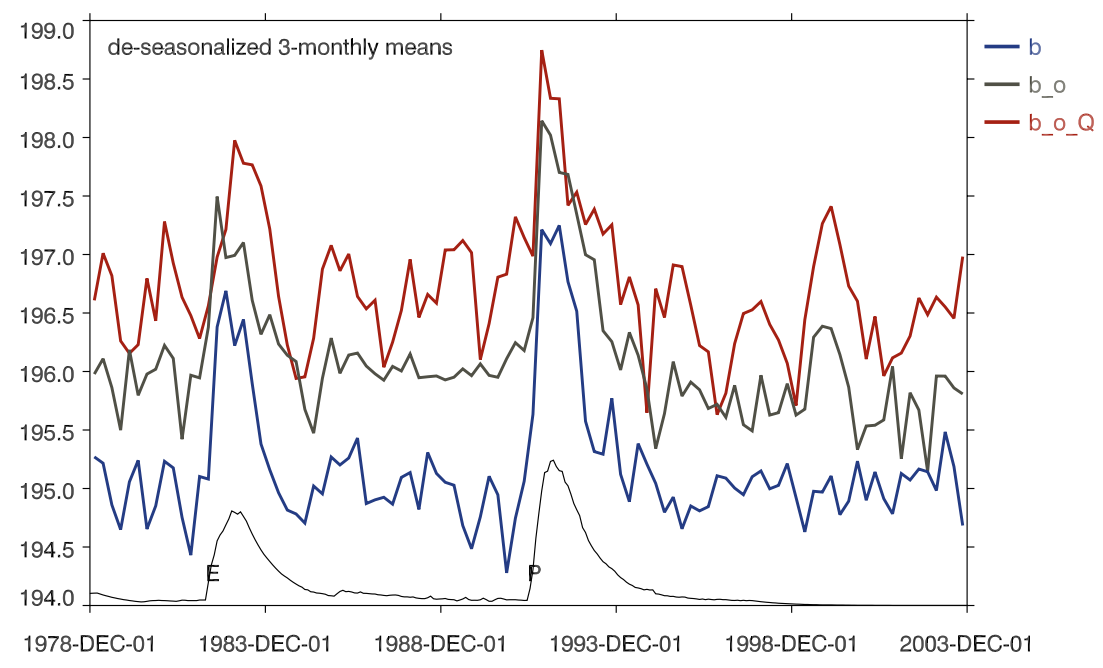

Water vapour (ppmv) at $100 \mathrm{hPa}$ in the equatorial region

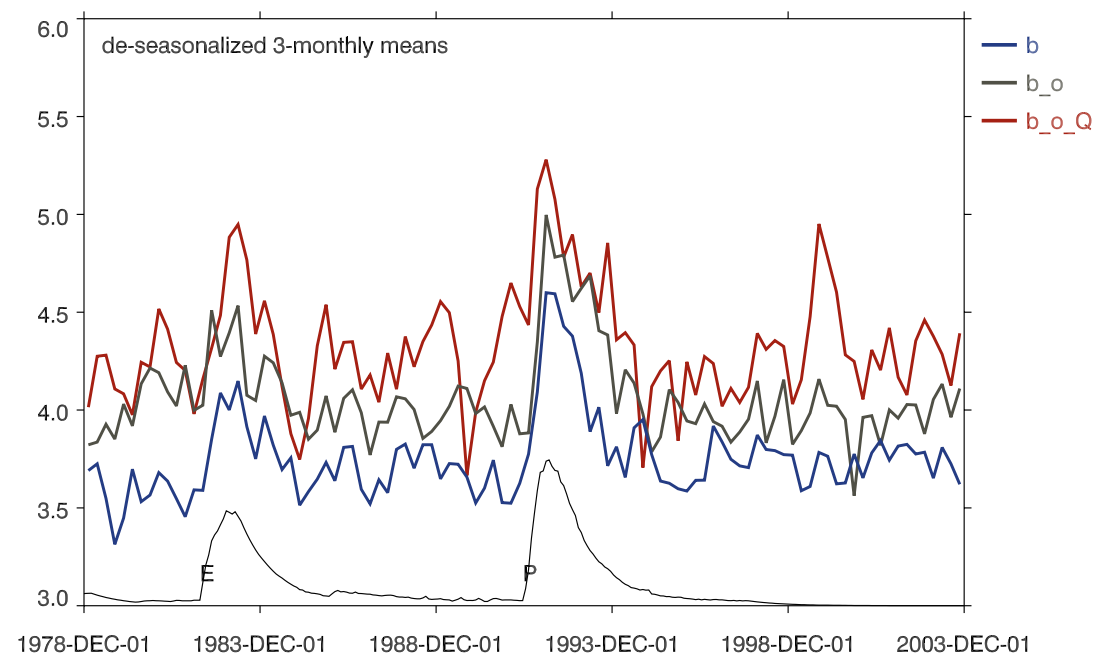

Baseline+ozone $+\mathrm{QBO}$ vs. baseline difference in water vapour (ppmv) at $100 \mathrm{hPa}$ in the equatorial region

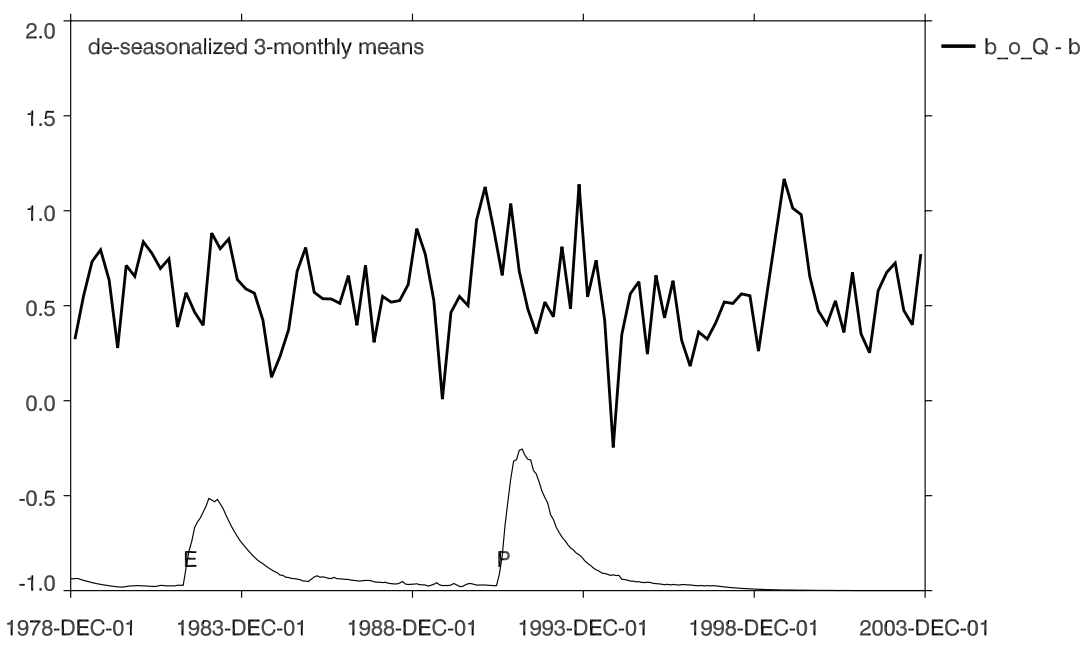


Fig. 3 As in Fig. 2 but for temperature $(\mathrm{K})$ and water vapour (ppmv) at $200 \mathrm{hPa}$ in the tropical region
Temperature $(\mathrm{K})$ at $200 \mathrm{hPa}$ in the tropical region

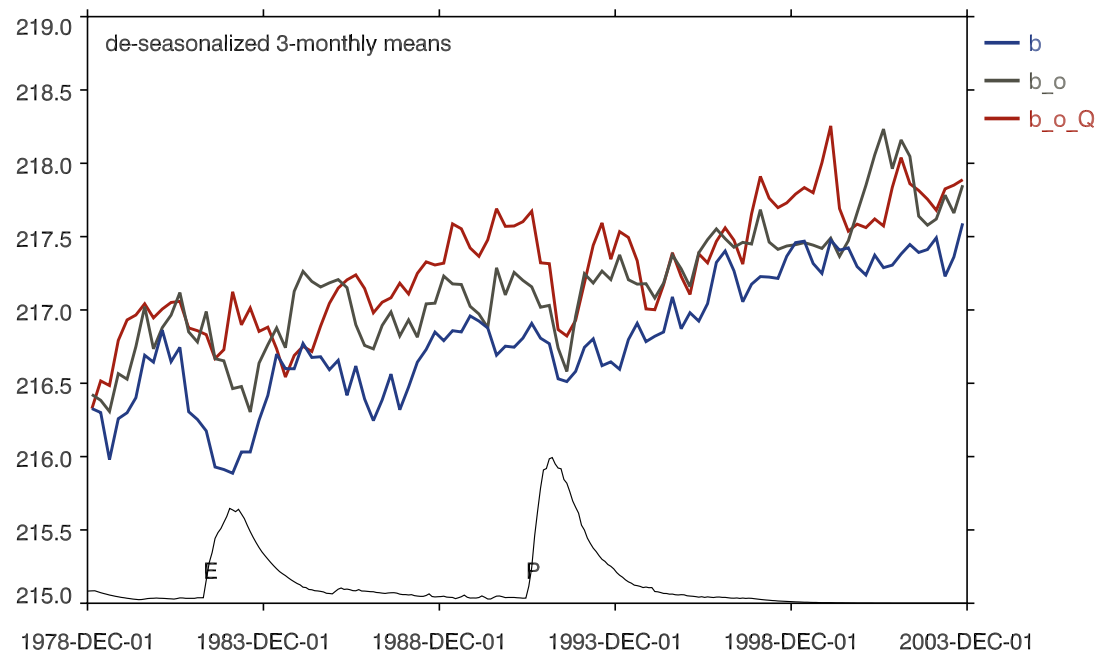

Water vapour (ppmv) at $200 \mathrm{hPa}$ in the tropical region

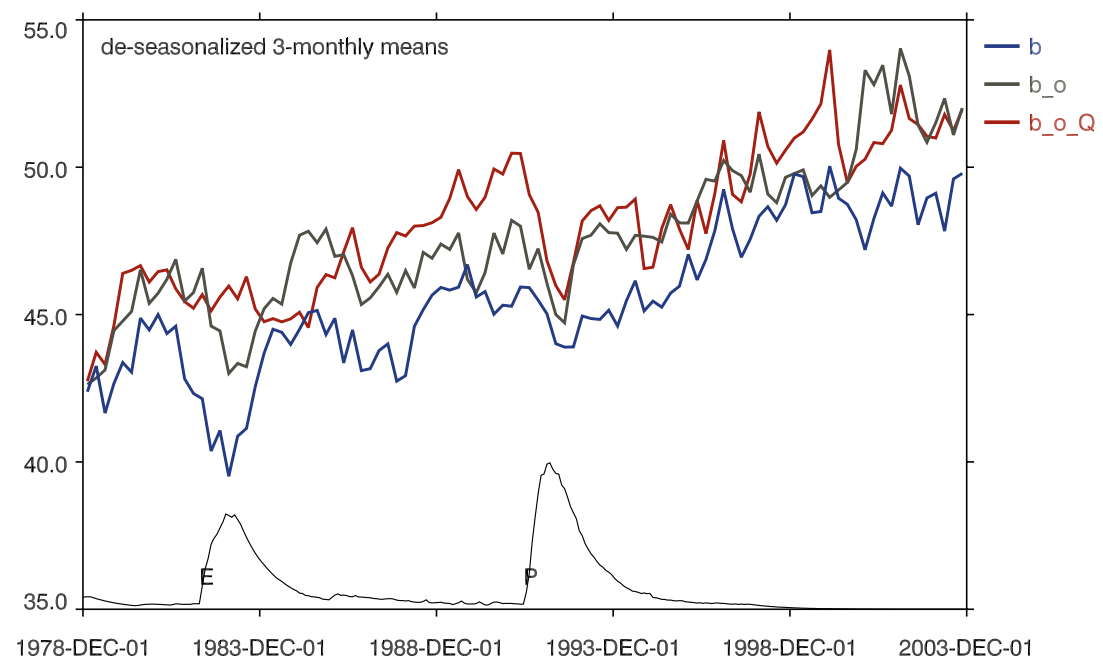

Baseline+ozone+QBO vs. baseline difference in water vapour (ppmv) at $200 \mathrm{hPa}$ in the tropical region

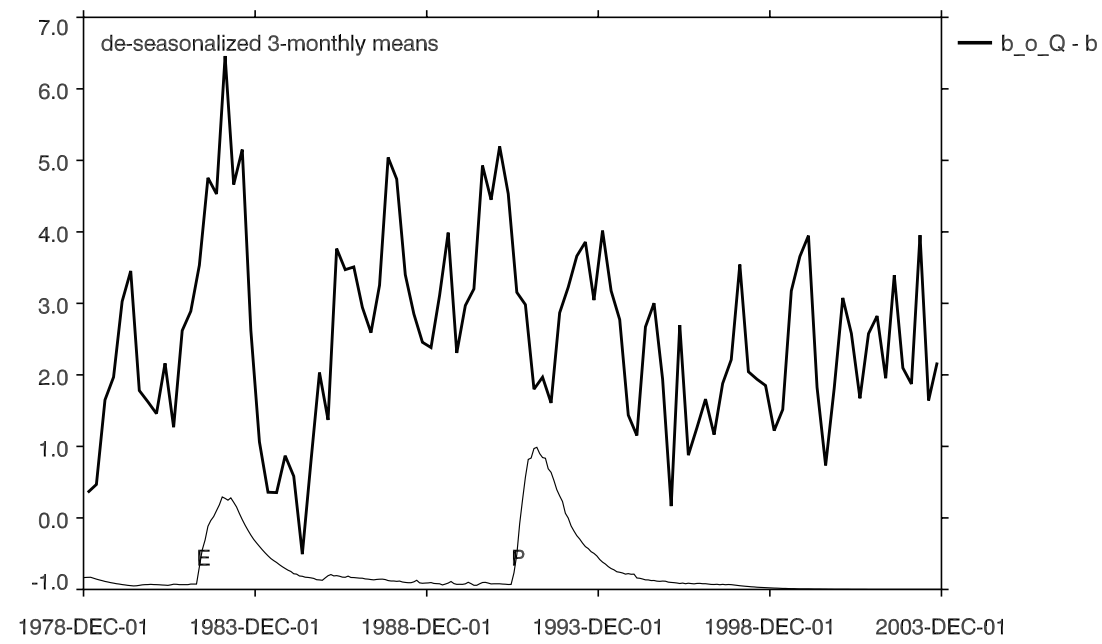


Fig. 4 Top evolution of nearsurface temperature $\left({ }^{\circ} \mathrm{C}\right)$ in the tropical region for the baseline (shades of blue) and baseline +ozone $+\mathrm{QBO}$ simulations (shades of orange). The thick black line gives the evolution of $2 \mathrm{~m}$ temperature in the ERA-40 re-analysis. Middle same as top panel but for global mean near-surface temperature. Bottom same as top panel but for $\mathrm{NH}$ extra-tropical nearsurface temperature
Near-surface temperature $\left({ }^{\circ} \mathrm{C}\right)$ in the tropical region

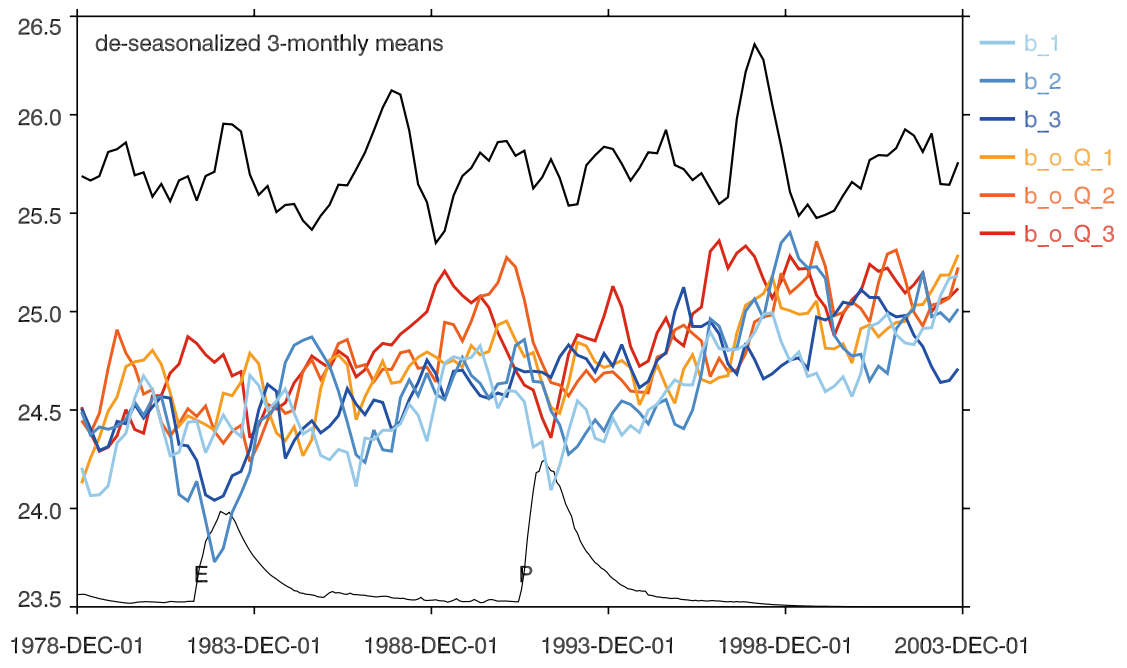

Global mean near-surface temperature $\left({ }^{\circ} \mathrm{C}\right)$

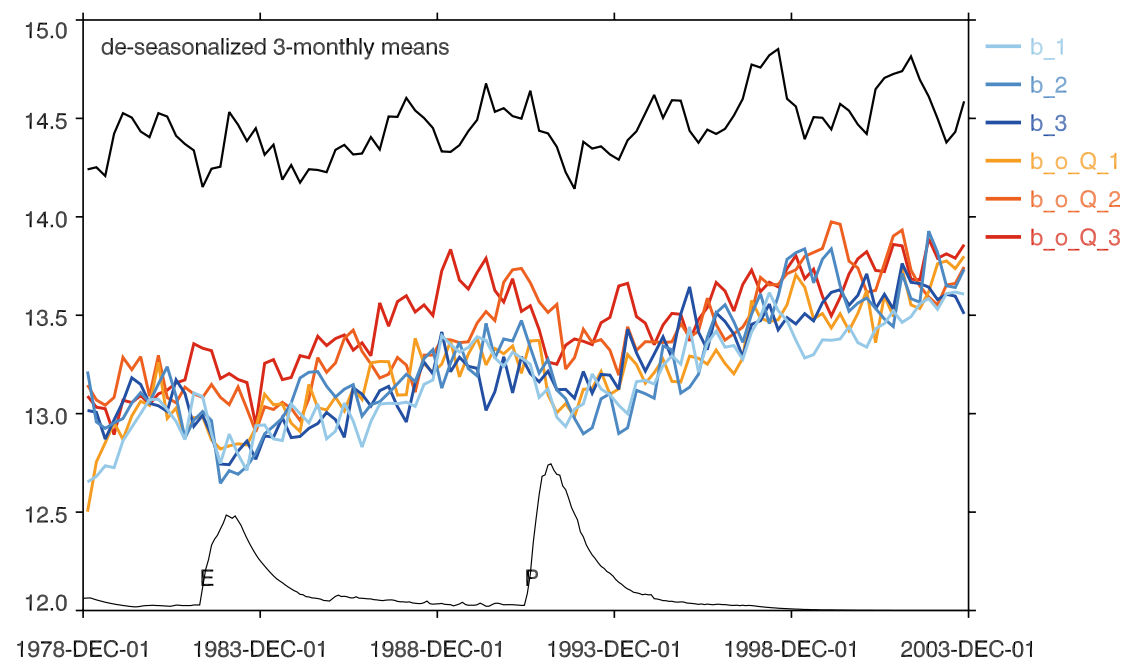

Near-surface temperature $\left({ }^{\circ} \mathrm{C}\right)$ in the $\mathrm{NH}$ extra-tropical region

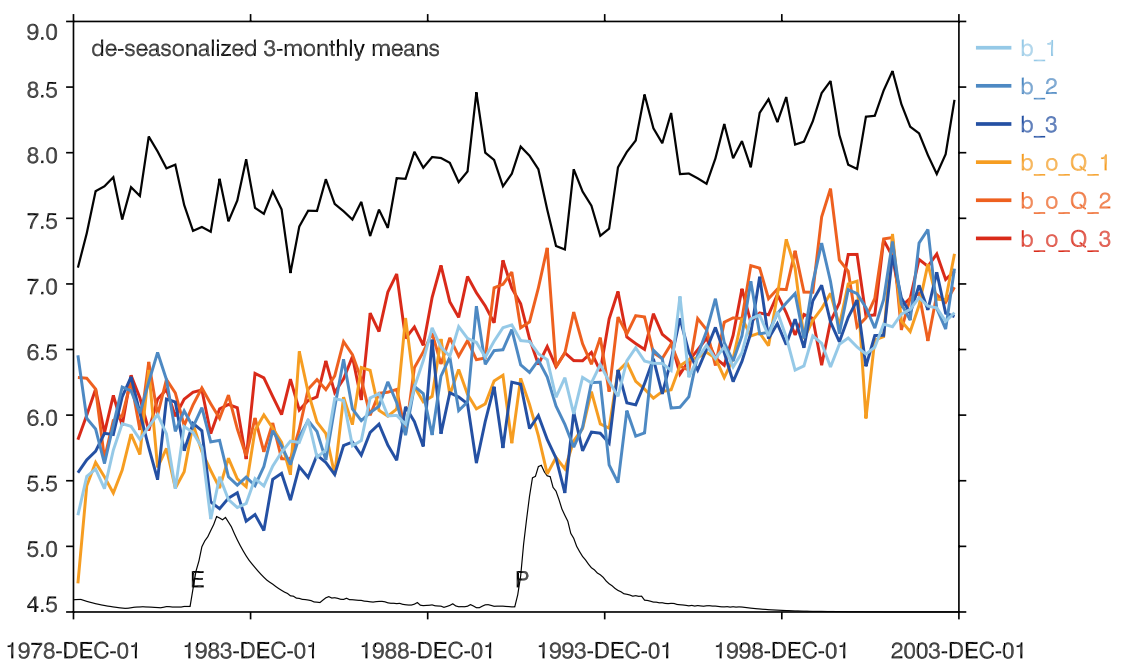


trends in the tropical ${ }^{2}$ and equatorial regions in each set of simulations are not significantly different from their global counterparts and hence the growth in modelled stratospheric water vapour cannot be ascribed to a significantly different average warming trend at the tropopause over these regions. Further studies are required in order to shed light on this issue.

The improved stratospheric representation also affects the variability of tropopause temperatures including different response to the El Chichón and Mt. Pinatubo eruptions due to the different phases of the QBO at the time of the two eruptions. In the equatorial region, tropopause temperature increases associated with the volcanic eruptions can be seen in all sets of simulations (top panel of Fig. 2). In addition, the temperature signal of the QBO may be seen in the baseline+ozone+QBO simulations. At the time of the El Chichón eruption, the QBO was at the end of a descending easterly phase in the lowermost stratosphere. The warming associated with the meridional circulation induced by the following descending westerly phase acts to slightly postpone and enhance the warming associated with the volcanic eruption. In addition, the associated reduced ascent results in a positive ozone anomaly and hence additional diabetic warming, although this latter effect contributes only about $20 \%$ of the resulting temperature anomaly ( $\mathrm{Li}$ et al. 1995). In contrast, during the Mt. Pinatubo eruption the QBO is at the onset of a descending easterly phase. The cooling and negative ozone anomaly induced by the associated ascent both contribute to reduce the volcanic warming signal in the lowermost stratosphere. In the equatorial region, the water vapour at $100 \mathrm{hPa}$ (middle panel) is representative of the water vapour at the tropopause and gives a qualitative indication of the water vapour that may reach the stratosphere through tropical upwelling (note that methane oxidation is not included in our simulations). The evolution of water vapour resembles that of temperature with the volcanic signal recognisable in all sets of simulations and the signal of the QBO in the baseline+ozone + QBO simulations.

\subsection{The upper tropical troposphere}

The improved stratospheric representation substantially reduces upper tropospheric warming trends in the tropical region. The climate models assessed by the AR4 give tropical warming trends that are stronger aloft than at the

\footnotetext{
2 In this paper, averages over the "tropical region" refer to area-mean averages over those grid points located between the tropics (about $23.5^{\circ} \mathrm{S}-23.5^{\circ} \mathrm{N}$ ), while the "equatorial region" implies a latitude belt of half the width of the tropical one and centred at the equator. Each extra-tropical region refers to grid points located poleward of the tropics while the Arctic and Antarctic regions refer to grid points located poleward of the circles.
}

surface while the upper tropical troposphere has shown a cooling in the observations in the last two decades of the twentieth century (Thorne et al. 2005; Cordero and Forster 2006). In the upper troposphere, the warming rate in the baseline+ozone $+\mathrm{QBO}$ simulations is about $0.05 \mathrm{~K} \mathrm{dec}-$ $\operatorname{ade}^{-1}$ lower than in the baseline and this difference is significant at the $10 \%$ level at $150 \mathrm{hPa}$ (not shown), where the trend is $0.37 \pm 0.01 \mathrm{~K} \mathrm{decade}^{-1}$ for the baseline simulations, $0.33 \pm 0.07$ for the baseline+ozone and $0.32 \pm 0.01$ for the baseline+ozone $+\mathrm{QBO}$ simulations with $P$ values of 0.625 and 0.060 , respectively, when compared to the baseline. As modelled trends in the baseline+ozone simulations are in between the trends in the other sets of simulations, this improvement comes from the improved ozone dataset as well as from the QBO relaxation (as suggested by Thorne et al. 2005). Near the surface, differences in trends are much reduced, indicating that the negative trend in lapse rate is slightly reduced in the baseline+ozone+QBO simulations. Note that data problems affecting observational uncertainty may also still contribute to explaining remaining differences (Santer et al. 2006).

The different phases of the QBO in the lowermost stratosphere discussed in the previous section cause a different response to the El Chichón and Mt. Pinatubo eruptions in the upper tropical troposphere. The evolution of the ensemble-mean temperature in the tropical region at $200 \mathrm{hPa}$ is shown in the top panel of Fig. 3. Two prominent differences between the ensemble-means are the reduced post-El Chichòn cooling and the increased post-Mt. Pinatubo cooling in the baseline+ozone+QBO simulations compared with the baseline, which is consistent with the evolution of tropopause temperatures in the equatorial region (top panel of Fig. 2). The results suggest that the temperature signal induced by the zonal wind QBO is a significant factor for tropical upper tropospheric temperature variability. The middle panel of Fig. 3 reports the evolution of the ensemble-mean water vapour at $200 \mathrm{hPa}$ in the tropical region, which closely resembles that of temperature.

We suggest a mechanism in which the induced circulation associated with the descending westerly phase of the QBO following the El Chichón eruption results in reduced equatorial ascent in the lowermost stratosphere and hence adiabatic warming in the lowermost stratosphere and upper tropical troposphere. The aerosol emitted by El Chichón, on the other hand, results in a cooling in the upper troposphere, but this effect is counteracted by the warming induced by the QBO leading to a time series of temperature and water vapour that behaves as if no eruption was taking place. During the Mt. Pinatubo eruption, the QBO was in a descending easterly phase, resulting in increased equatorial ascent which contributes 
to increased cooling and reduced temperatures. This effect therefore reinforces the cooling effect of the aerosol, leading to even greater cooling.

\subsection{Near the surface}

\subsubsection{Temperature trends and variability}

The improved stratospheric representation does not significantly affect global mean near-surface ${ }^{3}$ warming trends as may be seen in the middle panel of Fig. 4. The warming trend for the 1979-2003 period in the baseline and in the baseline+ozone $+\mathrm{QBO}$ simulations is $0.31 \pm 0.01$ and $0.29 \pm 0.01 \mathrm{~K} \mathrm{decade}^{-1}$, respectively, and these warming trends are consistent $(P$ value of 0.333). Our model simulations have a larger warming trend than the ERA-40 dataset which is about $0.12 \mathrm{~K}$ decade $^{-1}$, but ERA-40 has been shown to underestimate the warming trend, particularly in the SH (Simmons et al. 2004, their Fig. 1; Uppala et al. 2005, their Sect. 7b). The pure observational dataset HadCRUT3 (Brohan et al. 2006), also estimates a larger 1979-2003 temperature trend of about $0.19 \mathrm{~K} \mathrm{decade}^{-1}$. If masked according to the observational coverage (which excludes the rapidly warming polar regions), the all-forcings simulations with HadGEM1 described in Stott et al. (2006) give a warming trend of $0.25 \mathrm{~K} \mathrm{decade}^{-1}$ over this time period, which is much closer to the HadCRUT3 value. These warming trends also change when a different 25 -year time period is considered (25 years is a fairly short time for estimating warming trends) and remaining differences could be consistent with the effects of internal variability and observational uncertainties.

As for the offset of about $1 \mathrm{~K}$ between modelled and reanalysis values, note that the absolute global mean nearsurface air temperature is not known very accurately, being estimated to be within $0.5^{\circ} \mathrm{C}$ of $14^{\circ} \mathrm{C}$ (Jones et al. 1999) and anomalies relative to the 1961-1990 period rather than absolute values generally appear in the literature. The models assessed by the AR4 are generally cooler than observed (Randall et al. 2007, their Section 8.3.1). However, these models do capture the large-scale features of mean climate and variability and change sufficiently well to be able to have trust in their prediction of large-scale features of climate change.

An inspection of the evolution of modelled global mean near-surface temperature (middle panel of Fig. 4) reveals that internal variability appears to be substantially larger in the baseline+ozone+QBO simulations than in the baseline

\footnotetext{
${ }^{3}$ Unless otherwise specified, the "near-surface" temperature refers to the air temperature $1.5 \mathrm{~m}$ above the surface.
}

simulations. ${ }^{4}$ A statistical $F$ test of internal variance of global mean annual mean near-surface temperature is conducted as follows. The internal variance of a set of model simulations is obtained by subtracting the ensemble-mean. The null hypothesis is that this quantity has the same internal variance in the perturbed as well as in the reference simulations. The alternative hypothesis is that the perturbed simulations have a different internal variance than the reference. The two-sided test approach deriving from this null hypothesis is justified as a given direction for eventual changes cannot be expected a priori. Further, it is reasonable to assume a normal distribution since the climate diagnostics considered here are means over large surfaces and are estimated over periods of time beyond the de-correlation time scale of the considered processes. With such a statistical model, we can conduct an $F$ test as in von Storch and Zwiers (1999, Sect. 6.7.3). The test statistic is $F=s_{\text {per }}^{2} /$ $s_{\text {ref }}^{2}$ (where the subscripts "per" and "ref" stand for perturbed, baseline+ozone+QBO simulations, and reference, baseline, respectively), i.e. the ratio of sample internal variances in the two sets of simulations. The internal sample variance of global mean annual mean near-surface temperature is of about $0.006 \mathrm{~K}^{2}$ within the baseline simulations (sample standard deviation of about $0.08 \mathrm{~K}$ ) and of about $0.015 \mathrm{~K}^{2}$ within the baseline+ozone+QBO simulations (sample standard deviation of about $0.12 \mathrm{~K}$ ). The ratio of variances, i.e. the $F$ statistic is 2.45 . Considering the pooled lag 1 autocorrelation of both sets of time series (after subtraction of the respective ensemble-means) to calculate the degrees of freedom (see Zwiers and von Storch 1995; von Storch and Zwiers 1999, their subsection 6.6.7), a $P$ value of 0.007 is obtained and the null hypothesis of equal variances can be rejected at the $1 \%$ level.

The improved stratospheric representation increases near-surface temperature variability in the extra-tropical regions while decreasing variability in the tropics, giving an overall global increase in internal variability ${ }^{5}$ (compare

\footnotetext{
${ }^{4}$ In Sects. 3.3 and 3.4 we rarely mention the near-surface implications of the baseline+ozone simulations because the global mean near-surface temperature in their first ensemble member shows a drifts towards colder temperatures in the second half of the modelled time period when it stays well outside the range of variability of the remaining two ensemble members (not shown). This first ensemble member may suffer from its initial ocean state having been sampled relatively early into the control simulation with pre-industrial atmospheric composition (see Dall'Amico et al. 2009, their Sect. 2.1).

5 Note that if one considers spatial domains smaller than the global, variances can be expected to grow in both sets of simulations and their ratio can be expected to approach one. Further, the total variance is the sum of the variance at all frequencies: intra-seasonal variability adds to the variance in the baseline+ozone+QBO as well as in the baseline simulations. The ratio of these variances can be expected to approach 1 if, instead of annual means, means over shorter periods of time are considered (e.g. de-seasonalised 3-monthly means or seasonal means).
} 
also the panels in Fig. 4). In the baseline+ozone+QBO simulations, internal variance in the extra-tropical regions is greater than in the baseline, especially in $\mathrm{NH}$, where the internal variance ratio is highest in the DJF season and lowest in the SON season (not shown). This hints to a possible role of vertical coupling of $\mathrm{NH}$ stratospheric and tropospheric dynamics which is strongest in winter. However, the mechanism by which a larger internal variability in the troposphere might be driven by the changes applied to the stratosphere remains unclear. The reduction of variability in the tropics is most likely to be the result of the forced QBO, which relaxes towards exactly the same wind values in each of the baseline+ozone + QBO ensemble members. If the QBO had not been forced but internally generated, internal variance would have likely grown also in the tropical region because, after the first few years, the evolution of the QBO in each of the ensemble members would have been different. For the same reason, if the model were enhanced with a chemistry scheme, each ensemble member would have a different ozone field and thus internal variance would be expected to grow.

\subsubsection{Arctic warming}

The improved stratospheric representation makes a significant difference to modelled Arctic temperature response. The upper panel of Fig. 5 shows the ensemble-mean annual mean near-surface temperature trend patterns over the period 1979-2003 in the baseline simulations. The information is limited to grid boxes where the trend is different from zero with a $P$ value smaller than 0.100 . The Arctic region and the Sea of Okhotsk (located to the East of Siberia) show the strongest significant warming trends. In the baseline+ozone+QBO simulations (lower panel), warming trends in the Arctic region are above $1 \mathrm{~K} \mathrm{dec}$ ade $^{-1}$ with the Arctic Ocean warming substantially more rapidly than in the baseline simulations. A $t$ test conducted to test the null hypothesis that the region North of $71^{\circ} \mathrm{N}$ warms at the same rate in the baseline+ozone+QBO and in the baseline simulation gives a $p$ value of 0.093 , which decreases to 0.042 if the test is limited to grid points located North of $76^{\circ} \mathrm{N}$. Thus, a large portion of the Arctic Ocean warms at a significantly larger rate in the baseline+ozone+QBO simulations. Trends in the baseline+ozone simulations (not shown) are only slightly larger than in the baseline simulations. Given the scarcity of observations in the Arctic region, it is difficult to compare modelled warming trends with observations (see, e.g. Trenberth et al. 2007, the right panel of their Fig. 3.9) although our enhanced modelled warming in the Arctic represents a potential step forward in modelling Arctic climate.
The larger Arctic warming trend in the baseline + ozone $+\mathrm{QBO}$ simulations arises mainly in $\mathrm{NH}$ winter. In DJF, the differences are larger than in the annual mean (not shown). Further, this region shows significantly different trends also in the SON season (not shown). The fact that such differences arise in DJF and SON hints at a possible role for the vertical coupling of $\mathrm{NH}$ stratospheric and tropospheric dynamics which is strongest in winter. Possible mechanisms for stratospheric downward influence may be through enhancing the downwelling and warming in the Arctic and also the wave activity and consequent northward heat and moisture flux in the troposphere. In the JJA season, the baseline and the baseline+ozone+QBO simulations show no significantly different warming trends in the central portion of the Arctic Ocean (not shown).

Although not in the main scope of this paper, the fact that the strong modelled warming in the Arctic region occurs mainly in DJF and SON which is a common feature of the baseline and the improved stratosphere simulations, suggests that the albedo feedback related to sea ice melt may play only a minor role in the modelled Arctic warming. A strong contribution to modelled Arctic warming is likely to come from a shift in weather patterns towards more cloudy and snowy winters which are associated with milder temperature regimes which in turn affect the growth of sea ice. A substantial increase in winter precipitation in the Arctic region happens to be a persistent feature across AR4 model predictions for the twenty-first century (see, e.g. Fig. 3.3 of the Synthesis Report of the AR4 and the central panels of Fig. 10.9 of Meehl et al. 2007).

\subsubsection{Volcanic response}

Climate models tend to overestimate the post-volcanic cooling near the surface (Cordero and Forster 2006), even more so in the case of the El Chichón eruption which was followed by a strong El Niño event-Mt. Pinaubo's eruption was followed by a weak El Niño event. The near-surface cooling of the tropical region in the baseline simulations in the aftermath of both eruptions is similar, with two ensemble members out of three showing fairly substantial cooling (top panel of Fig. 4). The baseline+ozone simulations show a slightly stronger post El Chichón cooling and a similar post Mt. Pinatubo cooling to that of the baseline simulations (not shown). In contrast, in the baseline+ozone+QBO simulations there is no cooling after the El Chichón eruption but all ensemble members cool after the Mt. Pinatubo eruption. In re-analysis data it is difficult to separate internal variability from volcanic response and in the ERA-40 data there is no clear volcanic response with a slight warming in the year following the El Chichón eruption and a very slight cooling following Mt. Pinatubo's. 
Fig. 5 Upper modelled ensemble-mean trend $(\mathrm{K}$ decade $^{-1}$ ) for the baseline nearsurface temperature over the period 1979-2003. The information is limited to grid boxes where the trends are different from zero with a $P$ value below 0.100 . The black contour lines give the 0.050 and $0.010 P$ value isolines (thin and thicker, respectively, contour values in \%). Lower as in the upper panel but for the baseline + ozone $+\mathrm{QBO}$ simulations

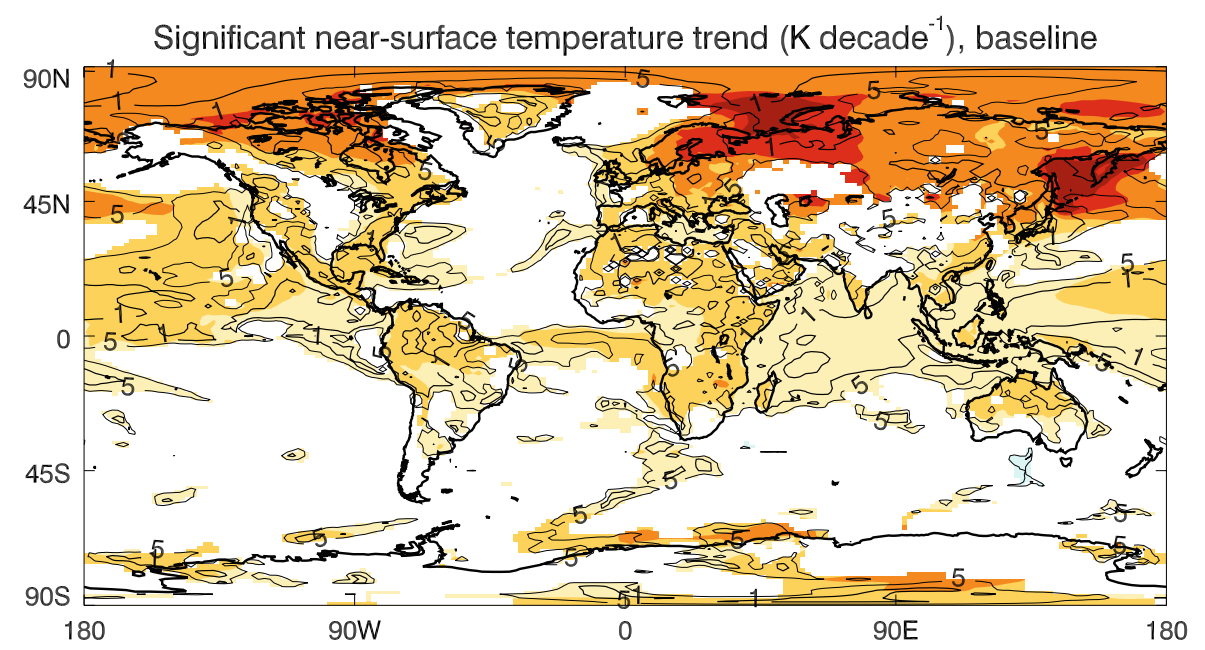

Significant near-surface temperature trend $\left(\mathrm{K}_{\text {decade }}{ }^{-1}\right)$, baseline + ozone $+\mathrm{QBO}$

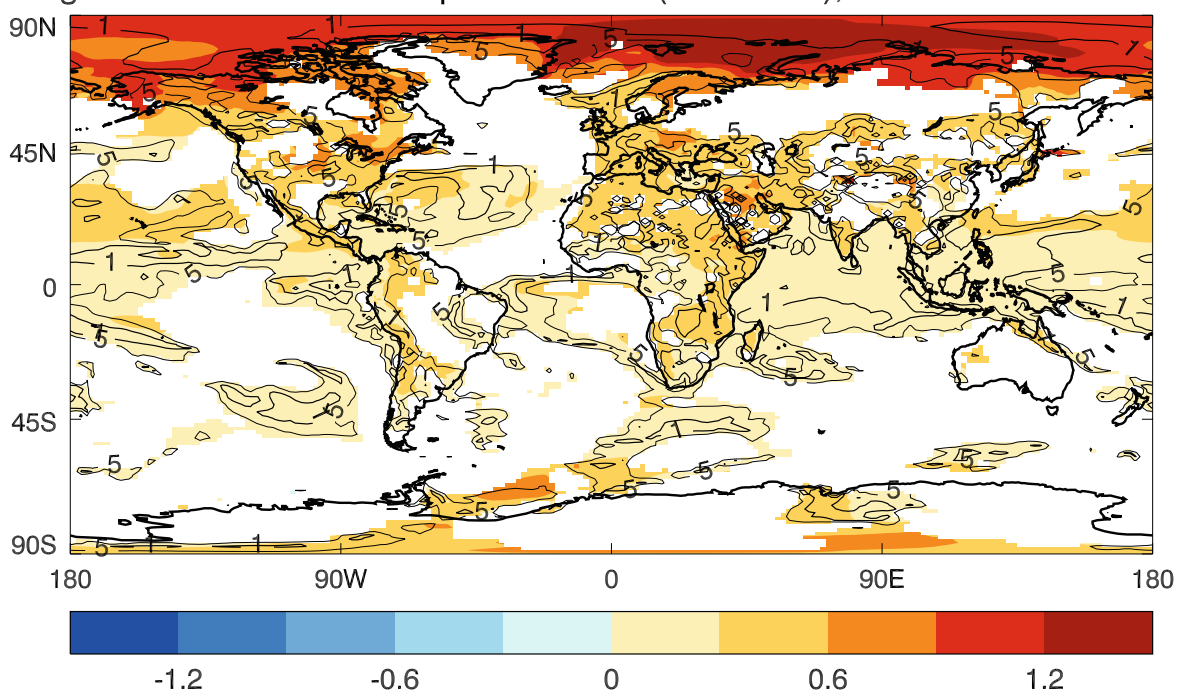

Given the rather small ensemble size, the difference in tropical near-surface volcanic response in the baseline + ozone + QBO simulations compared with the baseline could be due to coincidental El Niño events in the baseline + ozone + QBO simulations. In the aftermath of the El Chichón eruption, sea surface temperatures (SST) averaged over the El Niño 3.4 region (Fig. 6) are slightly warmer in the baseline+ozone $+\mathrm{QBO}$ simulations than in the baseline but there is some amount of overlap. Further, there are temperature increases in both sets of simulations. In the aftermath of the Mt. Pinatubo eruption, there is more variability and more overlap. A $t$ test suggests consistency of the annual mean Nino 3.4 SST values in the baseline+ozone + QBO and baseline simulations in the years centred on 1 June 1982 and 1983 (year of the El Chichón eruption and subsequent one) as well as in 1991 and 1992 (same for Mt. Pinatubo), with $P$ values above 0.200 . Overall, in the aftermath of both major recent volcanic eruptions there is insufficient difference in El Niño 3.4
SSTs which could account for the different evolution of tropical near-surface temperature in the baseline+ozone + QBO simulations. Thus, this different response is unlikely to be the result of fortuitous sampling of the model's internal climate variability and is likely to be associated with the QBO.

The mechanism discussed in Sect. 3.2 by which the QBO warms the upper tropical troposphere while the aerosol emitted by El Chichón is trying to cool it seems the most likely explanation for a time series of water vapour in the middle panel of Fig. 3 (red line) which behaves as if no eruption was taking place. In addition to this, changes in water vapour content induced by volcanic aerosol in the tropical upper troposphere and lower stratosphere (UTLS) can induce a radiative forcing which affects near-surface temperature. Joshi and Shine (2003) studied the increase of stratospheric water vapour related to increases in tropopause temperature due to volcanic eruptions and suggested that the corresponding radiative forcing counteracts 
Fig. 6 As in Fig. 4 but for the evolution of surface temperature $\left({ }^{\circ} \mathrm{C}\right)$ in the El Niño 3.4 region
Surface temperature $\left({ }^{\circ} \mathrm{C}\right)$ in the El Niño 3.4 region

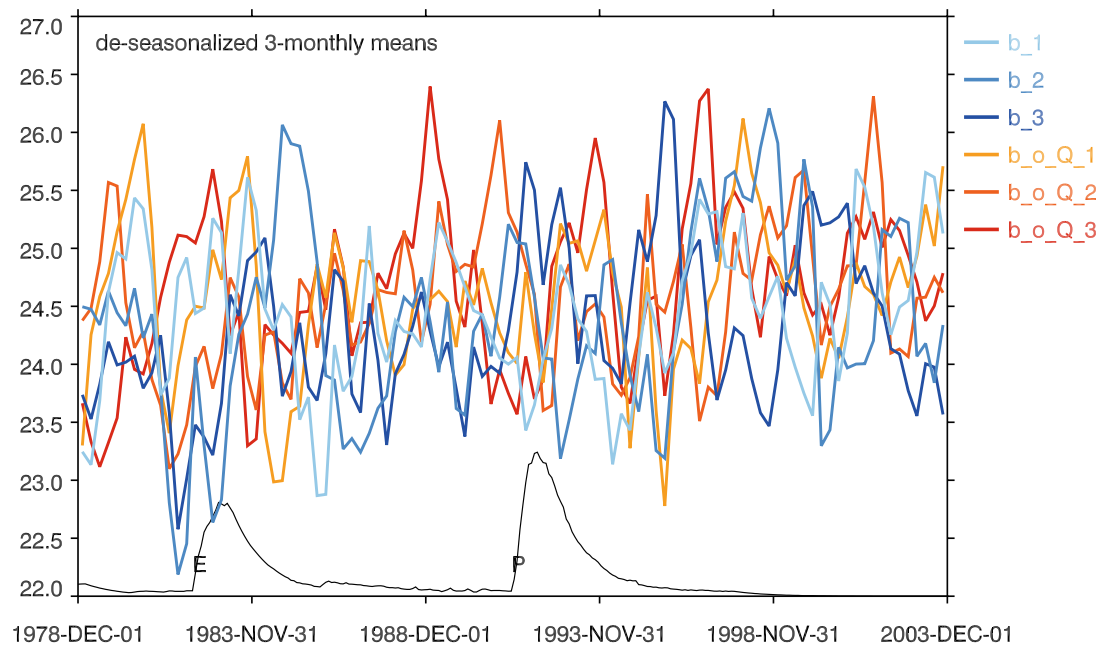

near-surface cooling. At the peak in stratospheric aerosol loading following the El Chichón eruption, the baseline + ozone $+\mathrm{QBO}$ versus baseline difference in water vapour at $100 \mathrm{hPa}$ is about $0.5 \mathrm{ppmv}$ larger than following the eruption of Mt. Pinatubo (bottom panel of Fig. 2). This difference can account for a radiative forcing of about $0.15 \mathrm{~W} \mathrm{~m}^{-2}$ (Forster and Shine 2002) which can explain only a small part of the change in modelled near-surface response in the tropical region. Lower down at $200 \mathrm{hPa}$, the baseline+ozone+QBO versus baseline difference in water vapour is 4 ppmv higher following the El Chichón eruption than after Mt. Pinatubo (bottom panel of Fig. 3).

A similar behaviour is observed in the time series of annual mean precipitation rate in the tropical region (Fig. 7). This is consistent with the different temperature and water vapour response. In the baseline simulations, there is a consistent and impressive drying in the aftermath of both volcanic eruptions (Fig. 7) and the same applies to the baseline+ozone simulations (not shown). The baseline+ozone $+\mathrm{QBO}$ simulations, however, show a similar drying only after the Mt. Pinatubo eruption and there is no such drying after El Chichón's. In the year following the El Chichón eruption (1983) there is no overlap in Fig. 7. For the ensemble-mean annual mean precipitation rate centred on 1 June 1983 , the $P$ value of a $t$ test is 0.117 , suggesting that it is somewhat unlikely that the two sets of values are consistent. Altogether, temperature changes in the upper tropical troposphere induced by the QBO can affect the chain of effects associated with volcanic aerosol by which less incoming shortwave radiation cools the surface, which in turn implies a drier troposphere and hence less downwelling long wave radiation, which further enhances surface cooling.

The QBO relaxation changes the near-surface response to the El Chichón eruption also at the global scale. The baseline simulations show a cooling of about $0.3^{\circ} \mathrm{C}$ in the aftermath of both major recent volcanic eruptions (middle panel of Fig. 4). The response in the baseline+ozone+QBO simulations to the El Chichón eruption, however, is substantially reduced while the response to the Mt. Pinatubo eruption is similar to the baseline. Similar changes to precipitation response to those seen in the tropical region are reflected also in global mean annual mean precipitation rate though reduced in magnitude (not shown). In ERA-40 there is no clear volcanic signal also at the global scale.

In the $\mathrm{NH}$ extra-tropical region, the volcanic response in the baseline+ozone+QBO simulations is reduced following both eruptions when compared to the baseline (bottom panel of Fig. 4). The post El Chichón cooling is reduced by about $0.3 \mathrm{~K}$, the post Mt. Pinatubo cooling by about $0.1 \mathrm{~K}$. These values are slightly larger in boreal spring (MAM). This region is likely to provide an offset to the increased post-Mt. Pinatubo cooling observed in the tropical region which explains the similar response of both sets of simulations at the global scale. Section 3.4.1 discusses one possible mechanism for the reduction in $\mathrm{NH}$ extra-tropical response. In ERA-40 there is no clear volcanic signal also in the NH extra-tropical region.

\subsection{Annular modes}

\subsubsection{Northern annular mode}

Observational studies of major tropical volcanic eruptions (e.g. Groisman 1992; Robock and Mao 1992, 1995; Robock 2000) have shown associated positive anomalies in the boreal winter NAM in the two winters following an eruption. The proposed mechanism involves the interaction of tropical processes and the stratospheric polar vortex 
Fig. 7 As in Fig. 4 but for the evolution of the annual mean precipitation rate $\left(\mathrm{mm} \mathrm{year}^{-1}\right)$ in the tropical region
Precipitation rate $\left(\mathrm{mm}\right.$ year $\left.^{-1}\right)$ in the tropical region

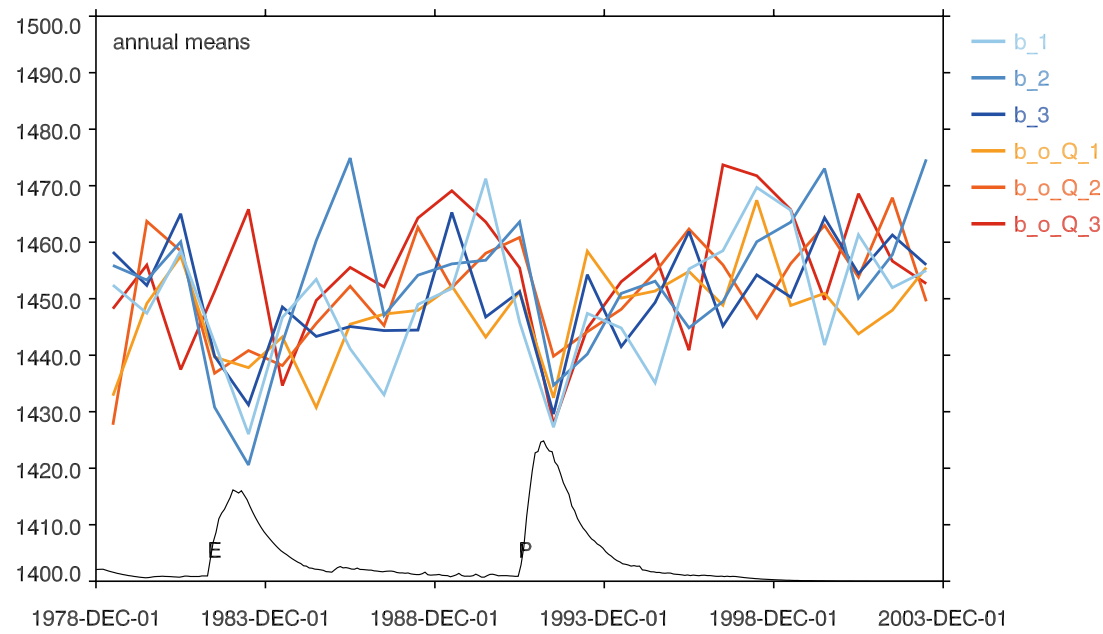

(Stenchikov et al. 2004). Increased stratospheric temperatures in the tropical region associated with the eruption (Dall'Amico et al. 2009, middle panel of their Fig. 3) increase the equator-to-pole temperature gradient and thus strengthen the polar vortex winds which results in a higher NAM index. In modelling the effect of a volcanic supereruption 100 times the magnitude of Mt. Pinatubo's, Jones et al. (2005) found a NH high latitude near-surface winter warming of up to $8^{\circ} \mathrm{C}$ in the following winter due both to a NAM increase and to changes in the longwave forcingthe North Atlantic thermohaline circulation also increased on a decadal timescale.

The QBO relaxation is associated with an enhanced NAM response following the El Chichón eruption, but not following Mt. Pinatubo's. Figure 8 shows the evolution of $50^{\circ} \mathrm{N}-60^{\circ} \mathrm{N}$ mean DJF zonal mean zonal wind at $50 \mathrm{hPa}$ (upper panel) and $100 \mathrm{hPa}$ (lower panel). This diagnostic is highly correlated with the NAM (Wallace 2000). After the El Chichón eruption, all three baseline+ozone+QBO simulations show a strengthening of the mean westerly flow (corresponding to a positive NAM phase) at $50 \mathrm{hPa}$ during the following two winters. This behaviour contrasts with the baseline simulations which show little change or a weakened NAM. Although the differences are still evident at $100 \mathrm{hPa}$, they diminish in the upper troposphere (not shown) and no change can be seen in the time series of the North Atlantic oscillation at the surface (not shown). In the post Mt. Pinatubo winters, the differences between the baseline and the baseline+ozone + QBO simulations are small. The baseline+ozone simulations show essentially the same behaviour as the baseline (not shown).

This behaviour could be associated with the different QBO phase, as suggested by Stenchikov et al. (2004) and supported by our results. In a modelling study, Stenchikov et al. (2004) found that a westerly QBO phase in the lower stratosphere results in an enhancement of the (tropical) volcanic aerosol effect on the winter NAM in the stratosphere and in the troposphere. A westerly QBO is associated with a strong undisturbed vortex (Holton and Tan 1980) which results in an additional cooling, thus adding to the volcanic cooling at high latitudes. For the DJF periods centred on 16 January 1983, 1984, 1992 and 1993, the ensemble-mean zonal mean zonal wind at $50 \mathrm{hPa}$ in the equatorial region in the baseline + ozone $+\mathrm{QBO}$ simulations is $5.0,-1.1,-4.8$ and $1.5 \mathrm{~m} \mathrm{~s}^{-1}$, respectively. Therefore, it is likely that the westerly QBO in the first post El-Chichòn $\mathrm{NH}$ winter has added to the volcanic response at high latitudes in the baseline+ozone + QBO simulations, leading to stronger westerlies and a more positive NAM. Analogously, the easterly QBO phase during the first post Mt. Pinatubo winter is likely to have led to a weaker polar vortex and hence weakened the effect of the eruption on the NAM.

Our small ensemble sizes preclude any clear conclusions and an accurate representation of the interaction between QBO and the NAM is hindered by the low model top at $5 \mathrm{hPa}$ and the poor vertical resolution in the middle stratosphere, which prevents the accurate simulation of planetary wave propagation. In our baseline + ozone $+\mathrm{QBO}$ simulations during boreal winter when the QBO is westerly (i.e. the equatorial winds at $50 \mathrm{hPa}$ are greater than or equal to $5 \mathrm{~m} \mathrm{~s}^{-1}$ ), the $50^{\circ} \mathrm{N}-60^{\circ} \mathrm{N}$ zonal wind at $50 \mathrm{hPa}$ is only $1.9 \mathrm{~m} \mathrm{~s}^{-1}$ stronger than when the QBO is easterly. This difference grows to $6.6 \mathrm{~m} \mathrm{~s}^{-1}$ at $10 \mathrm{hPa}$, bus this is less than half the magnitude of the corresponding signal in the ERA-40 dataset (Pascoe et al. 2005, their Fig. 5). Due to the strong variability among the three ensemble members, our modelled QBO West-minus-East differences in the NAM are not significantly different from zero (the $P$ value is 0.352 at $50 \mathrm{hPa}$ and 0.149 at $10 \mathrm{hPa}$ ). This demonstrates that the Holton and Tan (1980) relationship is poorly reproduced in the model. 
Fig. 8 As in Fig. 4 but for DJF zonal mean zonal wind $\left(\mathrm{m} \mathrm{s}^{-1}\right)$ at $50 \mathrm{hPa}$ (upper panel) and $100 \mathrm{hPa}$ (lower panel) averaged over the $50^{\circ} \mathrm{N}-60^{\circ} \mathrm{N}$ region
DJF zonal wind $\left(\mathrm{m} \mathrm{s}^{-1}\right)$ at $50 \mathrm{hPa}$ in the $50^{\circ} \mathrm{N}$ to $60^{\circ} \mathrm{N}$ region

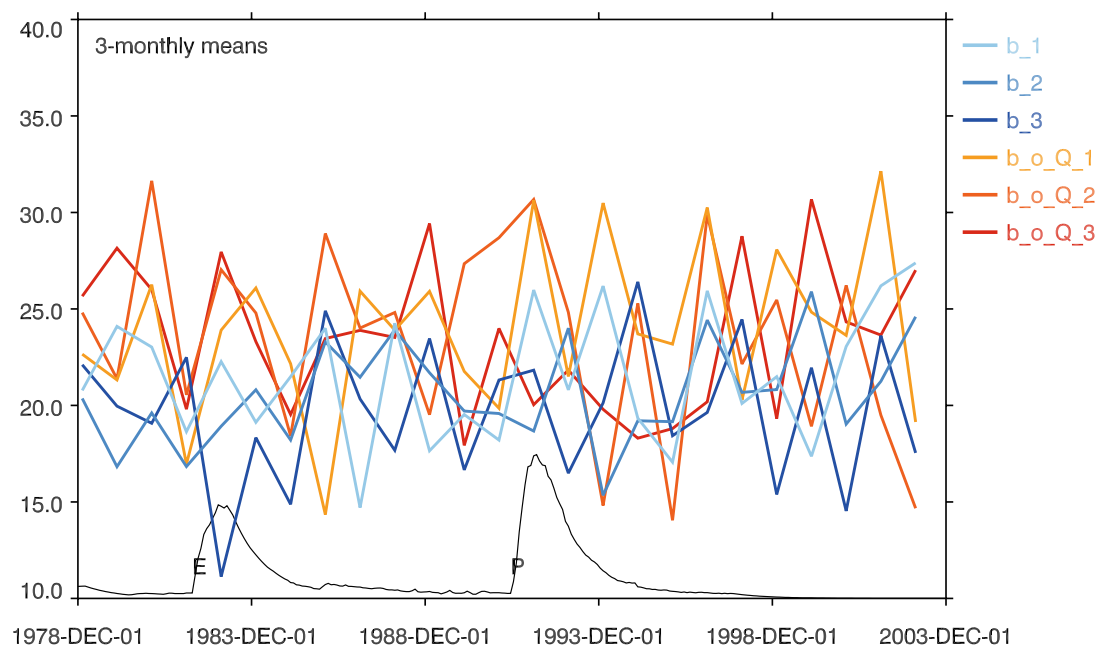

DJF zonal wind $\left(\mathrm{m} \mathrm{s}^{-1}\right)$ at $100 \mathrm{hPa}$ in the $50^{\circ} \mathrm{N}$ to $60^{\circ} \mathrm{N}$ region

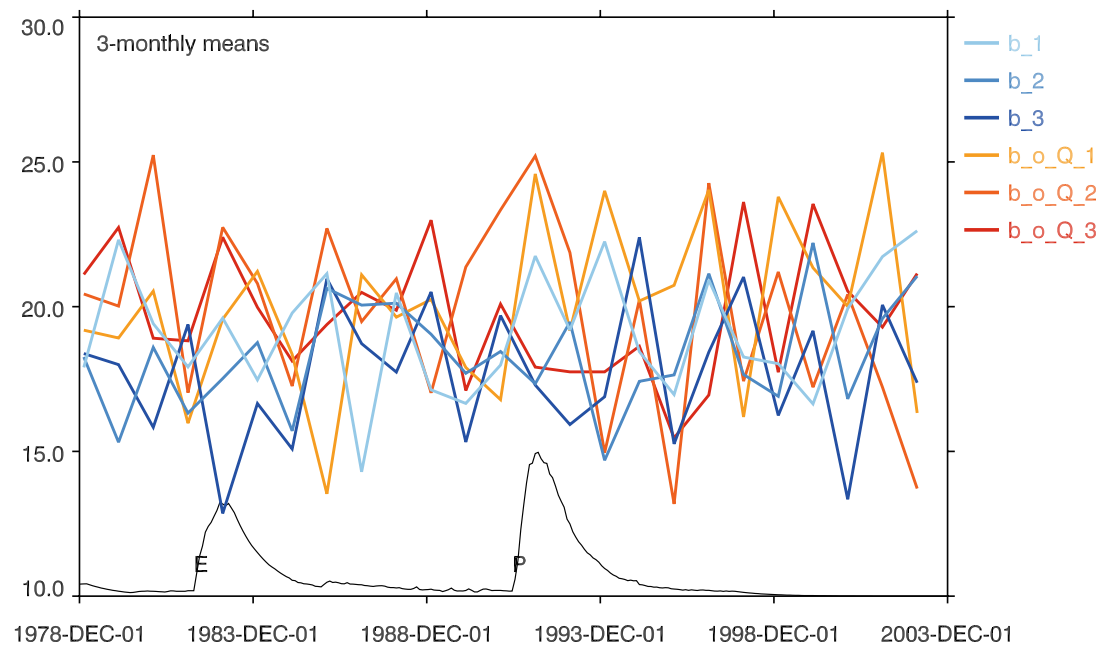

For the 1978-2003 period, the DJF trend of the NAM of the baseline+ozone $+\mathrm{QBO}$ simulations is consistent with zero and also with both the baseline+ozone and the baseline trends at stratospheric and tropospheric levels ${ }^{6}$ including the surface NAO.

\subsubsection{Southern annular mode}

Climate change in the $\mathrm{SH}$ in recent decades has been marked by a strengthening of the westerlies in the stratosphere as well as in the troposphere (e.g. Hurrel and van Loon 1994; Thompson and Solomon 2002) in particular during austral summer and autumn months. These trends are reflected as a bias towards positive anomalies of the southern annular mode (SAM) (Thompson and Solomon

\footnotetext{
${ }^{6}$ We considered the $50^{\circ} \mathrm{N}-60^{\circ} \mathrm{N}$ zonal wind at $50,100,200$ and $500 \mathrm{hPa}$.
}

2002; see also Fig. 3 of Marshall et al. 2004) and have been associated with the cooling over Antarctica in SH summer and the warming over the Antarctic Peninsula (Thompson and Solomon 2002; Gillet and Thompson 2003). Thompson and Solomon (2002) suggested that the SAM trend in the troposphere during $\mathrm{SH}$ summer months is consistent with forcing by stratospheric ozone depletion. Gillet and Thompson (2003) reproduced seasonality, structure and amplitude of the observed SAM trends using a fullstratosphere resolving model coupled to a mixed-layer ocean with prescribed stratospheric ozone depletion.

Improving the QBO and ozone representation in our model reduces the intra-ensemble variability and increases the ensemble-mean of the December-May SAM trend response in the model. The upper panel of Fig. 9 reports for the baseline simulations the December-May ensemblemean pressure at mean sea level (pmsl) trend patterns. The information is limited to grid boxes where the trend is 
significantly different from zero with a $P$ value smaller than 0.100 . Although these simulations are forced with an ozone dataset that includes the negative trend in $\mathrm{SH}$ stratospheric ozone related to anthropogenic ozone depletion, it does not show a pattern corresponding to a positive SAM trend with a decrease in geopotential height over Antarctica and an increase over mid-latitudes (e.g. Thompson and Solomon 2002). If no grid boxes are excluded by the statistical significance testing, then the pattern has a similar structure to the positive SAM trend observed in re-analysis data (Gillett et al. 2005, their Fig. 1). However, the variability among the ensemble members is such that this trend is not statistically significant. In contrast, in the baseline+ozone+QBO simulations (lower panel) a significant SAM-like pattern emerges.

In order to obtain a reliable observational proxy of the SAM, Marshall (2003) adjusted the definition proposed by Gong and Wang (1999) to pmsl values based on the mean of station records near $40^{\circ} \mathrm{S}$ and $65^{\circ} \mathrm{S}$, i.e. the latitudes used in the definition. Using principally NCEP-NCAR reanalysis data (Kalnay et al. 1996; Kistler et al. 2001), Marshall (2003) found that the station-based difference between values near $40^{\circ} \mathrm{S}$ and $65^{\circ} \mathrm{S}$ (henceforth station-based SAM) explained $86 \%$ of the zonal mean pmsl difference (henceforth zonal mean SAM) for monthly data. Thus, it is reasonable to compare modelled zonal mean SAM trends with Marshall's station-based SAM trend. The baseline and the baseline + ozone $+\mathrm{QBO}$ ensemble-mean zonal mean SAM trends are $0.75 \pm 0.40$ and $1.03 \pm 0.18 \mathrm{hPa}$ decade $^{-1}$, respectively. The baseline trend does not significantly differ from zero ( $P$ value of 0.198 ) while the baseline + ozone + QBO trend does, at the $5 \%$ level $(P$ value of 0.029). This result is consistent with Fig. 9. The baseline+ozone trend with $0.70 \pm 0.21$ is similar to the baseline in the mean but with less intra-ensemble variability and when compared to zero, it gives a $P$ value of 0.078 , which lies in between. The observed station-based SAM trend is larger with $-1.78 \mathrm{hPa}$ decade $^{-1}$ and thus, the baseline+ozone+QBO ensemble-mean zonal mean SAM trend is closer to the observed value than the baseline.

This improvement cannot be ascribed only to the likely improved trend in ozone loss in the observed ozone dataset compared with that related to the EESC in the baseline ozone dataset. The rate of ozone decline in the observed ozone in the Antarctic region is about half the magnitude of the baseline ozone at almost all stratospheric model levels and the near-surface ensemble-mean zonal mean SAM trend in the baseline+ozone simulations is slightly weaker than in the baseline. The zonal mean trend in the baseline+ozone+QBO simulations is larger than in the baseline+ozone and baseline simulations, suggesting that the QBO is also likely to have had an impact on the nearsurface SAM trend over this time period.
While anthropogenic ozone depletion is likely to have had a major impact on recent SH trends in pmsl, these results suggest that internal variability in the stratosphere is likely to have a large impact on this timescale. Thus, the recent trend of the SAM may be subject, to a large extent, to stratospheric internal variability on decadal timescales. If so, this may explain why AR4 models forced by ozone trends similar to those imposed in the baseline simulations, typically underestimate the magnitude of the observed negative geopotential trends in the Antarctic troposphere (Karpechko et al. 2008).

In future, inter-annual variability in addition to stratospheric ozone recovery will affect circulation changes and their impact on surface temperatures. Studies conducted with chemistry climate models with imposed SST trends predict a recovery of SH stratospheric ozone within the next $60-70$ years (Eyring et al. 2007). In such model studies, SH tropospheric westerlies are predicted to decelerate in summer in contrast with most AR4 models (Perlwitz et al. 2008; Son et al. 2008), and this could accelerate warming rates in the Antarctic region. From our study, it emerges that inter-annual variability in the stratosphere is likely to affect near-surface climate trends both in the Arctic (Sect. 3.3.2) and in the Antarctic region (this section). Both the inter-annual variability in ozone and the phase of the QBO are unpredictable on decadal timescales. Therefore, the above results call for caution in evaluating modelled climate change in the $\mathrm{SH}$ extra-tropical region and in particular the near-surface impact of the predicted future recovery of stratospheric ozone.

\section{Conclusions}

In this paper, we study the impact of improvements in the representation of stratospheric variability on climate simulations of recent decades, using a global coupled atmosphere ocean model with natural and anthropogenic forcings. In both sets of perturbed simulations (baseline+ozone and baseline+ozone+QBO), the stratospheric ozone distribution in our model was replaced with a dataset including observed inter-annual variability. In addition to this, in the baseline+ozone+QBO simulations a QBO relaxation was applied to stratospheric zonal winds.

The most surprising result in our study is that global mean annual mean near-surface temperature variance is significantly larger in the baseline+ozone + QBO simulations. This result is also fairly robust as it is significant at the $1 \%$ level. Although variance decreases in the tropics, where internal variability is likely to be more constrained through the imposed QBO, the increase in variance in the extratropics, especially in $\mathrm{NH}$, more than compensates this. 
Fig. 9 Upper panel as in Fig. 5 but for December-May pressure at mean sea level (pmsl) trend $\left(\mathrm{hPa}\right.$ decade $\left.^{-1}\right)$ in the baseline simulations. Lower as in the upper panel but for the baseline+ozone+QBO simulations

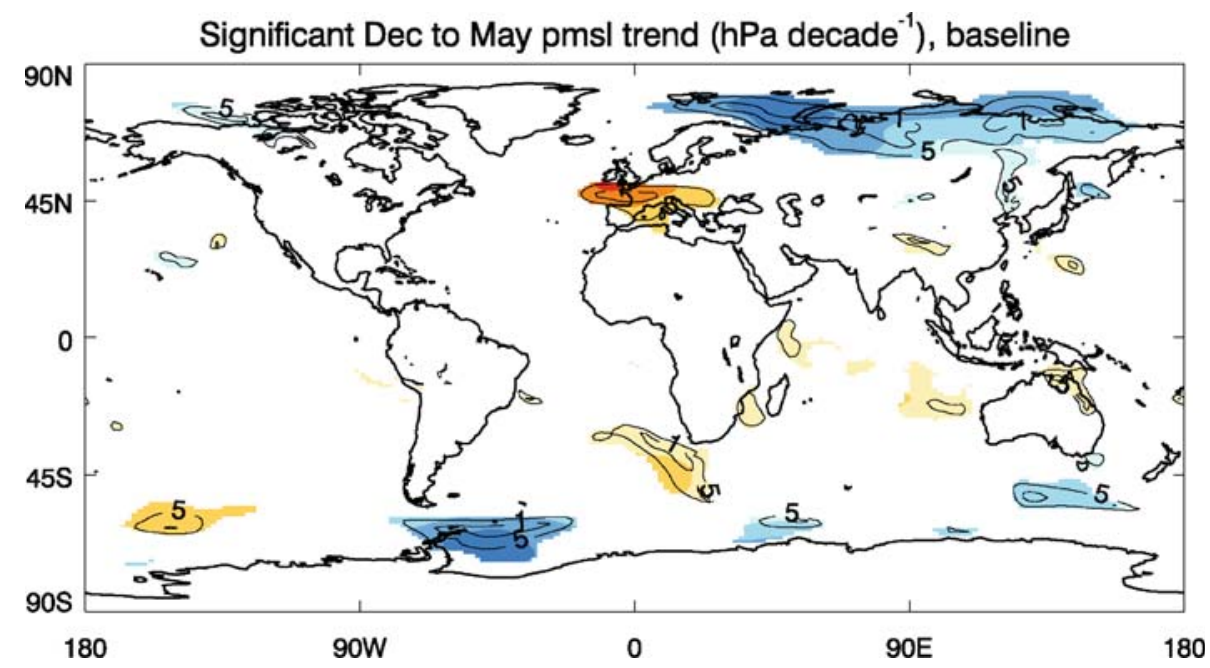

Significant Dec to May pmsl trend ( $\mathrm{hPa}$ decade ${ }^{-1}$ ), baseline+ozone+QBO

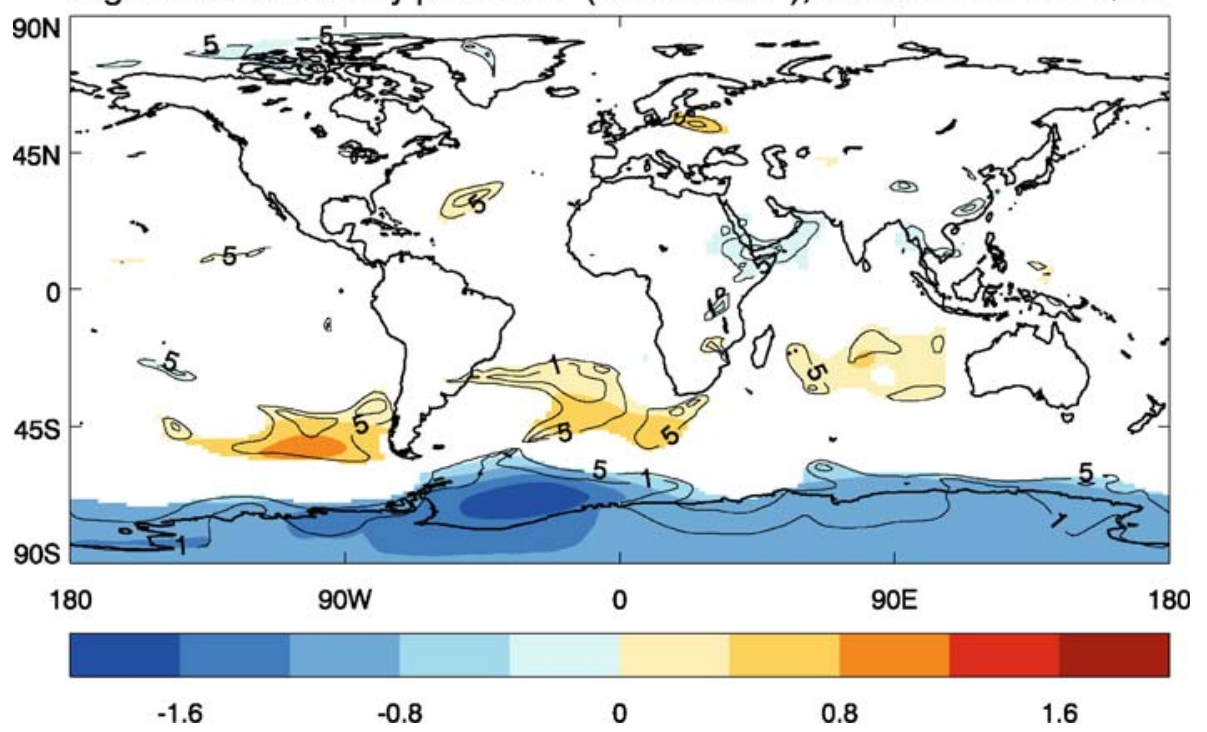

The near-surface warming trend in a large portion of the Arctic Ocean is significantly larger in the baseline+ ozone+QBO simulations than in the baseline. This result is significant at the 5\% level in the centre of the Arctic Ocean. This change arises in the SON season and even more so in the DJF season. This points at a role of NH stratosphere-troposphere coupling which is strongest in boreal winter.

The baseline+ozone+QBO simulations reproduce a significant December-May trend pattern in SH pmsl in agreement with the observed positive trend in the SAM and a positive trend in the SAM that is closer to observations. The baseline simulations, where anthropogenic ozone depletion was present as a forcing factor, yield no significant trend. This suggests that near-surface variability in SH high latitudes is to a large extent subject to stratospheric internal variability even on decadal timescales. This result calls for caution in evaluating the tropospheric effects of predicted stratospheric ozone recovery.

In the baseline+ozone+QBO simulations, the nearsurface temperature and precipitation response to the El Chichón eruption is substantially weakened, in particular in the tropical region. The temperature signal induced by the QBO in the upper tropical troposphere counteracts the cooling induced by volcanic aerosol, leading to a time series of water vapour behaving as if no volcanic eruption was taking place.

The winter increase in the phase of the NAM observed in the aftermath of the two major recent volcanic eruptions is partly reproduced in the baseline+ozone+QBO simulations in the stratosphere, in particular in the aftermath of the El Chichón eruption-but this signal does not penetrate deep into the troposphere. 
Warming trends in the upper tropical troposphere are slightly reduced in the baseline+ozone simulations and even more so in the baseline + ozone $+\mathrm{QBO}$ simulations where the warming trends are reduced by about $0.05 \mathrm{~K}$ decade $^{-1}$. This hints to a role for ozone and the QBO in explaining any remaining discrepancy between the vertical structure in modelled and observed temperature trends over this period.

The modelled cooling rate of the tropopause almost doubles when the improved ozone distribution and the QBO are included. Thus, the improved stratospheric representation has an important effect which could help resolve some of the discrepancies between observed and modelled cooling rates at the tropopause.

Although changes were applied strictly to the stratosphere only in our perturbed sets of simulations, we obtain here some significant effects on climate at lower levels, in particular near the surface. Such differences could, in some cases, explain some apparent discrepancies between climate model simulations and observations, although internal variability and observational uncertainties are likely to play an important role. Our results highlight the importance of stratospheric processes for climate change, even at tropospheric levels, and motivate attention being given to improving their representation in coupled atmosphere ocean climate model simulations of recent decades. This study shows that the simulation of recent climate change may be improved by using an ozone dataset with observed variability and a relaxation to the QBO. However, the lack of an NAO trend and the poor reproduction of the Holton and Tan (1980) effect suggest that it is desirable to improve the model's representation of the middle and upper stratosphere. This seems feasible since the growing horizontal resolution at which the models are run requires, for consistency reasons, a growing vertical resolution, and in any case the few extra levels required in the upper stratosphere would increase the computational cost only by a linear factor. Full chemistry in simulations of recent decades would be ideal, but this will be rather expensive and multiple ensembles are very important (Hare et al. 2005).

As for simulations of future decades (see also the discussion in Baldwin et al. 2007), our results suggest that the inclusion of ozone variability and the QBO can be an important factor in capturing the actual extent of the internal natural variability of near-surface climate as well as the evolution of large-scale patterns of climate change. Ozone variability can be included by expanding the model's complexity with a full chemistry scheme. An ozone time series consistent with the background meteorology is of course desirable but the computational cost should be carefully pondered. Another option would be to use a set of time series of ozone distributions obtained from climatechemistry model simulations forced with SSTs and sea ice datasets obtained from a previous set of coupled atmosphere ocean model runs. Modelling the QBO requires a gravity-wave parameterization scheme for its generation.

In conclusion, our results show some of the benefits of incorporating stratospheric dynamics and chemistry in climate models. Given the growing availability of high performance computing resources, we suggest that careful consideration should be given to improving the representation of stratospheric processes in climate change simulations spanning the twentieth and twenty-first centuries.

Acknowledgments Funding was provided by the UK National Environment Research Council. Peter Stott and Adam Scaife were supported by the Joint DECC, Defra and MoD Integrated Climate Programme-DECC/Defra (GA01101), MoD (CBC/2B/0417_Annex C5). We wish to thank Keith Shine, Terry Davies, Jason Lowe, Gareth Jones, Scott Osprey, Warwick Norton, Jonathan Gregory, Oliver Browne, Gareth Marshall, Michael Ponater, Robert Sausen and Veronika Eyring for their help in acquiring and processing data, their illuminating suggestions and their support. We also wish to thank all those people at the UK Met Office and various UK Universities who contributed throughout the years to the development of the Hadley Centre Global Environmental Model and ancillary datasets.

\section{References}

Baldwin MP, Dunkerton TJ (1999) Propagation of the Arctic Oscillation from the stratosphere to the troposphere. J Geosphys Res 104:30937-30946

Baldwin MP, Gray LJ, Dunkerton TJ, Hamilton K, Haynes PH, Randel WJ, Holton JR, Alexander MJ, Hirota I, Horinouchi T, Jones DBA, Kinnersley JS, Marquardt C, Sato K, Takahashi M (2001) The quasi-biennial oscillation. Rev Geophys 39:179-229

Baldwin MP, Stephenson DB, Thompson DWJ, Dunkerton TJ, Charlton AJ, O'Neill A (2003) Stratospheric memory and skill of extended-range weather forecasts. Science 301:636-640

Baldwin MP, Dameris M, Shepherd TG (2007) How will the stratosphere affect climate change? Science 316:1576-1577

Black RX (2002) Stratospheric forcing of surface climate in the Arctic Oscillation. J Clim 15:268-277

Boville BA (1984) The influence of the polar night jet on the tropospheric circulation in a GCM. J Atmos Sci 41:1132-1142

Brohan P, Kennedy JJ, Harris I, Tett SFB, Jones PD (2006) Uncertainty estimates in regional and global observed temperature changes: a new dataset from 1850. J Geophys Res 111:D12106. doi:10.1029/2005JD006548

Collimore CC, Hitchman M, Martin DW (1998) Is there a quasibiennial oscillation in tropical deep convection? Geophys Res Lett 25:333-336

Collimore CC, Martin DW, Hitchman M, Huesmann A, Waliser D (2003) On the relationship between the QBO and tropical deep convection. J Clim 16:2552-2568

Cordero EC, Forster PM de F (2006) Stratospheric variability and trends in models used for the IPCC AR4. Atmos Chem Phys 6:5369-5380

Coughlin K, Tung K-K (2001) QBO signal found at the extratropical surface through Northern annular modes. Geophys Res Lett 28:4563-4566

Croocks S, Gray LJ (2005) Characterization of the 11-year solar signal using a multiple regression analysis of the ERA-40 dataset. J Clim 18:996-1015 
Dall'Amico M, Egger J (2007) Empirical Master equations. Part II: Application to stratospheric QBO, solar cycle, and Northern annular mode. J Atmos Sci 64:2296-3015

Dall'Amico M, Gray LJ, Rosenlof, KH, Scaife AA, Shine KP, Stott PA (2009) Stratospheric temperature trends: impact of ozone variability and the QBO. Clim Dyn. doi:10.1007/s00382-0090604-x

Daniel JS, Solomon S, Albritton DL (1995) On the evaluation of halocarbon radiative forcing and global warming potentials. J Geophys Res 100:1271-1285

Eyring V, Waugh DW, Bodeker GE, Cordero E, Akiyoshi H, Austin J, Beagley SR, Boville BA, Braesicke P, Brühl C, Butchart N, Chipperfield MP, Dameris M, Deckert R, Deushi M, Frith SM, Garcia RR, Gettelman A, Giorgetta MA, Kinnison DE, Mancini E, Manzini E, Marsh DR, Matthes S, Nagashima T, Newman PA, Nielsen JE, Pawson S, Pitari G, Plummer DA, Rozanov E, Schraner M, Scinocca JF, Semeniuk K, Shepherd TG, Shibata K, Steil B, Stolarski RS, Tian W, Yoshiki M (2007) Multimodel projections of stratospheric ozone in the 21 st century. J Geophys Res 112:D16303. doi:10.1029/2006JD008332

Forster PM de F, Shine KP (2002) Assessing the climate impact of trends in stratospheric water vapor. Geophys Res Lett 29, doi 10.1029/2001GL013909

Forster PM, Bodeker GE, Schofield R, Solomon S, Thompson D (2007) Effects of ozone cooling in the tropical lower stratosphere and upper troposphere. Geophys Res Lett 34. doi:10.1029/ 2007GL031994

Gillet NP, Thompson WJ (2003) Simulation of recent Southern hemisphere climate change. Science 302:273-275

Gillett NP, Allan RJ, Ansell TJ (2005) Detection of external influence on sea level pressure with a multi-model ensemble. Geophys Res Lett 32:L19714. doi:10.1029/2005GL023640

Giorgetta MA, Bengtsson L, Arpe K (1999) An investigation of QBO signals in the East Asian and Indian monsoon in GCM experiments. Clim Dyn 15:435-450

Gong D, Wang S (1999) Definition of Antarctic oscillation index. Geophys Res Lett 26:459-462

Gray LJ, Pyle JA (1989) A two dimensional model of the quasibiennial oscillation of ozone. J Atmos Sci 46:203-220

Groisman PY (1992) Possible regional climate consequences of the Pinatubo eruption: an empirical approach. Geophys Res Lett 19:1603-1606

Haigh JD (2003) The effects of solar variability on the Earth's climate. Phil Trans R Soc Lond 361:95-111

Haigh JD, Blackburn M, Day R (2005) The response of tropospheric circulation to perturbations in lower stratospheric temperature. J Clim 18:3672-3685

Hansen J, Sato M, Ruedy R (1997) Radiative forcing and climate response. J Geophys Res 102:6831-6864

Hare SHE, Gray LJ, Lahoz WA, O'Neill A (2005) On the design of practicable numerical experiments to investigate stratospheric temperature change atmos. Sci Lett 6(2):123-127. doi: 10.1002/asl.101

Holton JR, Tan H-C (1980) The Influence of the equatorial quasibiennial oscillation on the global circulation at $50 \mathrm{mb}$. J Atmos Sci 37:2200-2208

Houghton JT, Ding Y, Griggs DJ, Noguer M, van der Linden PJ, Xiaosu D (eds) (2001) Climate change 2001: the scientific basis. Cambridge University Press, London

Hurrel JW, van Loon H (1994) A modulation of the atmospheric annual cycle in the Southern Hemisphere. Tellus A 46:325-338

Intergovernmental Panel on Climate Change: Climate Change (2007) The physical science basis: working group I contribution to the fourth assessment report of the IPCC. Cambridge University Press, London
Johns TC, Durman CF, Banks HT, Roberts MJ, McLaren AJ, Riddley JK, Senior CA, Williams KD et al (2006) The new Hadley Centre climate model (HadGEM1). Evaluation of coupled simulations. J Clim 19:1327-1353

Jones PD, New M, Parker DE, Martin S, Rigor IG (1999) Surface air temperature and its changes over the past 150 years. Rev Geophys 37:173-199

Jones GJ, Gregory JM, Stott PA, Tett SFB, Thorpe RB (2005) An AOGCM simulation of the climate response to a volcanic supereruption. Clim Dyn 25:725-738

Joshi M, Shine KP (2003) A GCM study of volcanic eruptions as a cause of increased stratospheric water vapour. J Clim 16:35253534

Kalnay E et al (1996) The NCEP/NCAR 40-year reanalysis project. Bull Am Meteorol Soc 77:437-441

Karpechko AYu, Gillett NP, Marshall GJ, Scaife AA (2008) Stratospheric influence on circulation changes in the Southern Hemisphere troposphere in coupled climate models. Geophys Res Lett 35:L20806. doi:10.1029/2008GL035354

Kiehl JT, Schneider TL, Poltmann RW, Solomon S (1999) Climate forcing due to tropospheric and stratospheric ozone. J Geophys Res 104:31239-31254

Kindem IT, Christiansen B (2001) Tropospheric response to stratospheric ozone loss. Geophys Res Lett 28:1547-1550

Kistler R et al (2001) The NCEP-NCAR 50-year reanalysis: monthly means CD-ROM and documentation. Bull Am Meteorol Soc $82: 247-267$

Labitzke K, van Loon H (1999) The stratosphere: phenomena, history, and relevance. Springer, Heidelberg

Lacis AA, Wuebbles DJ, Logan JA (1990) Radiative forcing of climate by changes in the vertical distribution of ozone. J Geophys Res 95:9971-9981. doi:10.1029/90JD00092

Li D, Shine KP, Gray LJ (1995) The role of ozone-induced diabatic heating anomalies in the quasibiennial oscillation. Q J R Meteorol Soc 121:937-943

Marshall GJ (2003) Trends in the Southern annular mode from observations and reanalyses. J Clim 16:4134-4143

Marshall GJ, Stott PA, Turner J, Connolley WM, King JC, LachlanCope TA (2004) Causes of exceptional atmospheric circulation changes in the Southern Hemisphere. Geophys Res Lett 31:L14205. doi:10.1029/2004GL019952

Martin GM, Ringer MA, Pope VD, Jones A, Dearden C, Hinton TJ (2006) The Physical properties of the atmosphere in the new Hadley Centre global environmental model (HadGEM1). Part I: Model description and global climatology. J Clim 19:1274-1301

Meehl GA, Stocker TF, Collins WD, Friedlingstein P, Gaye AT, Gregory JM, Kitoh A, Knutti R, Murphy JM, Noda A, Raper CB, Watterson IG, Weaver AJ, Zhao Z-C (2007) Global climate projections. In: Solomon S, Qin D, Manning M, Chen Z, Marquis M, Averyt KB, Tignor M, Miller HL (eds) Climate change 2007: the physical science basis. Contribution of working group I to the fourth assessment report of the intergovernmental panel on climate change, chap 10. Cambridge University Press, Cambridge

Norton WA (2003) Sensitivity of Northern Hemisphere surface climate to simulation of the stratospheric polar vortex. Geophys Res Lett 30. doi:10.1029/2003GL016958

Pascoe CL, Gray LJ, Crooks SA, Juckes MN, Baldwin MP (2005) The quasi-biennial oscillation: analysis using ERA-40 data. J Geophys Res 110:D08105. doi:10.1029/2004JD004941

Perlwitz J, Pawson S, Fogt RL, Nielsen JE, Neff WD (2008) Impact of stratospheric ozone hole recovery on Antarctic climate. Geophys Res Lett 35:L08714. doi:10.1029/2008GL033317

Randall DA, Wood RA, Bony S, Colman R, Fichefet T, Fyfe J, Kattsov V, Pitman A, Shukla J, Srinivasan J., Stouffer RJ, Sumi 
A, Taylor KE (2007) Climate models and their evaluation. In: Solomon S, Qin D, Manning M, Chen Z, Marquis M, Averyt K B, Tignor M, Miller HL (eds) Climate change 2007: the physical science basis. Contribution of working group I to the fourth assessment report of the intergovernmental panel on climate change. Cambridge University Press, Cambridge

Randel WJ, Wu F (1995) TOMS total ozone trends in potential vorticity coordinates. Geophys Res Lett 22:683-686

Randel WJ, Wu F (1999) A stratospheric ozone trends dataset for global modelling. Geophys Res Lett 26:3089-3092

Randel WJ, Wu F (2007) A stratospheric ozone distribution data set for 1979-2005: variability, trends, and comparisons with column ozone data. J Geophys Res 112:D06313. doi:10.1029/ 2006JD007339

Randel WJ, Stolarski R, Cunnold DM, Logan JA, Newchurch MJ, Zawodny JM (1999) Trends in the vertical distribution of ozone. Science 285:1689-1692

Reed RJ, Campbell WJ, Rasmussen LA, Rogers DG (1961) Evidence of the downward-propagating annual wind reversal in the equatorial stratosphere. J Geophys Res 66:813-818

Ringer MA, Martin G, Greeves C, Hinton T, Inness P, James P, Pope V, Scaife J, Slingo AA, Stratton R, Yang G (2006) The physical properties of the atmosphere in the New Hadley Centre Global Atmospheric Model (HadGEM1): Part II: Global variability and regional climate. J Clim 19:1302-1326

Robock A (2000) Volcanic eruptions and climate. Rev Geophys 38:191-219

Robock A, Mao J (1992) Winter warming from large volcanic eruptions. Geophys Res Lett 19:2405-2408

Robock A, Mao J (1995) The volcanic signal in surface temperature observations. J Clim 8:1086-1103

Santer BD, Wehner MF, Wigley TML, Sausen R, Meehl GA, Taylor KE, Ammann C, Arblaster J, Washington WM, Boyle JS, Bruggemann W (2003) Contributions of anthropogenic and natural forcings to recent tropopause height changes. Science 301:479-483

Santer BD, Wigley TML, Simmons AJ, Kållberg PW, Kelly GA, Uppala SM, Ammann C, Boyle JS, Brüggemann W, Doutriaux C, Fiorino M, Mears C, Meehl GA, Sausen R, Taylor KE, Washington WM, Wehner MF, Wentz FJ (2004) Identification of anthropogenic climate change using a second-generation reanalysis. J Geophys Res 109:D21104. doi:10.1029/2004JD005075

Santer BD, Penner JE, Thorne PW (2006) How well can the observed vertical temperature changes be reconciled with our understanding of the causes of these changes? In: Karl TR, Hassol SJ, Miller CD, Murray WL (eds) Temperature trends in the lower atmosphere: steps for understanding and reconciling differences. A report by the climate change science program and the subcommittee on global change research, Washington, DC, USA

Sausen R, Santer BD (2003) Use of changes in tropopause height to detect human influences on climate. Meteorol Z 12:131-136

Scaife AA, Knight JR, Vallis GK, Folland CK (2005) A stratospheric influence on the winter NAO and North Atlantic surface climate. Geophys Res Let 32:L18715

Seidel DJ, Randel WJ (2006) Variability and trends in the global tropopause estimated from radiosonde data. J Geophys Res 111. doi:10.1029/2006JD007363

Simmons AJ, Jones PD, da Costa Bechtold V, Beljaars ACM, Kållberg PW, Saarinen S, Uppala SM, Viterbo P, Wedi N (2004) Comparison of trends and low-frequency variability in CRU, ERA-40 and NCEP/NCAR analyses of surface air temperature. J Geophys Res 109:D24115. doi:10.1029/2004JD005306

Son SW, Polvani LM, Waugh DW, Akiyoshi H, Garcia R, Kinnison D, Pawson S, Rozanov E, Sheperd TG, Shibata K (2008) The impact of stratospheric ozone recovery on the Southern
Hemisphere Westerly Jet. Science 320:1486-1489. doi:10.1126/ science. 1155939

Stenchikov G, Hamilton K, Robock A, Ramaswamy V, Schwarzkopf MD (2004) Arctic oscillation response to the 1991 Pinatubo eruption in the SKyHI general circulation model with a realistic quasi-biennial oscillation. J Geophys Res 109. doi:10.1029/ 2003JD003699

Stott PA, Tett SFB, Jones GS, Allen MR, Jngram WJ, Mitchell JFB (2001) Attribution of twentieth century temperature change to natural and anthropogenic causes. Clim Dyn 17:1-21

Stott PA, Jones GS, Lowe JA, Thorne P, Durman C, Johns TC, Thelen J-C (2006) Transient climate simulations with the HadGEM1 climate model: causes of past warming and future climate change. J Clim 19:2763-2782

Stuber N, Ponater M, Sausen R (2005) Why radiative forcing might fail as a predictor of climate change. Clim Dyn 24:497-510

Tett SFB, Jones GS, Stott PA, Hill DC, Michell JFB, Allen MR, Ingram WJ, Johns TC, Johnson CE, Jones A, Roberts DL, Sexton DMH, Woodage MJ (2002) Estimation of natural and anthropogenic contributions to twentieth century temperature change. J Geophys Res 107(16):4306. doi:10.1029/2000JD000028

Thompson DWJ, Solomon S (2002) Interpretation of recent Southern Hemisphere climate change. Science 296:895-899

Thompson DW J, Wallace JM (2000) Annular modes in the extratropical circulation Part I: Month-to-month variability. J Clim 13:1000-1016

Thompson DWJ, Baldwin MP, Wallace MJ (2002) Stratospheric connection to Northern Hemisphere wintertime weather: implications for predictability. J Clim 15:1421-1428

Thorne PW, Karl TR, Coleman H, Folland CK, Murray WL, Parker DE, Ramaswamy V, Rossow WB, Scaife AA, Tett SFB (2005) Vertical profiles of temperature trends. Bull Am Meteorol Soc 86:1472-1476

Trenberth KE, Jones PD, Ambenje P, Bojariu R, Easterling D, Klein Tank A, Parker D, Rahimzadeh F, Renwick J A, Rusticucci M, Soden B, Zhai P (2007) Observations: surface and atmospheric climate change. In: Solomon S, Qin D, Manning M, Chen Z, Marquis M, Averyt KB, Tignor M, Miller HL (eds) Climate change 2007: the physical science basis. Contribution of working group I to the fourth assessment report of the intergovernmental panel on climate change. Cambridge University Press, Cambridge

Uppala SM, Kållberg PW, Simmons AJ, Andrae U, Bechtold VD, Fiorino M, Gibson JK, Haseler J, Hernandez A, Kelly GA, Li X, Onogi K, Saarinen S, Sokka N, Allan RP, Andersson E, Arpe K, Balmaseda MA, Beljaars ACM, Van De Berg L, Bidlot J, Bormann N, Caires S, Chevallier F, Dethof A, Dragosavac M, Fisher M, Fuentes M, Hagemann S, Holm E, Hoskins BJ, Isaksen L, Janssen PAEM, Jenne R, McNally AP, Mahfouf JF, Morcrette JJ, Rayner NA, Saunders RW, Simon P, Sterl A, Trenberth KE, Untch A, Vasiljevic D, Viterbo P, Woollen J (2005) The ERA-40 re-analysis. Q J R Meteorol Soc 131:2961-3012

van Loon H, Labitzke K (1987) The Southern Oscillation Part V: The anomalies in the lower stratosphere of the Northern Hemisphere in winter and a comparison with the quasi-biennial oscillation. Mon Weather Rev 115:357-369

Veryard RG, Ebdon RA (1961) Fluctuations in tropical stratospheric winds. Meteorol Mag 90:125-143

von Storch H, Zwiers FW (1999) Statistical analysis in climate research. Cambridge University Press, London

Wallace JM (2000) North Atlantic Oscillation/annular mode: two paradigms-one phenomenon. Q J R Meteorol Soc 126:791-805

Zwiers FW, von Storch H (1995) Taking serial correlation into account in tests of the mean. J Clim 8:336-351 